U.S. Department of the Interior

U.S. Geological Survey

Prepared in cooperation with the

Oregon Department of Transportation

\title{
The Effect of Calcium Magnesium Acetate (CMA) Deicing Material on the Water Quality of Bear Creek, Clackamas County, Oregon, 1999
}

Water-Resources Investigations Report 00-4092 
U.S. Department of the Interior

U.S. Geological Survey

Prepared in cooperation with the

Oregon Department of Transportation

\section{The Effects of Calcium Magnesium Acetate (CMA) Deicing Material on the W ater Quality of Bear Creek, Clackamas County, Oregon, 1999}

Water-Resources Investigations Report 00- 4092 


\section{U.S. Department of the Interior}

U.S. Geological Survey

\section{The Effects of Calcium Magnesium Acetate (CMA) Deicing $M$ aterial on the $W$ ater Quality of B ear Creek, Clackamas County, Oregon, 1999}

\section{By DWIGHT Q. TANNER and TAM ARA M, W OOD}

Water-Resources Investigations Report 00-4092

Prepared in cooperation with the

Oregon Department of Transportation 


\section{U.S. DEPARTMENT OF THE INTERIOR \\ BRUCE BABBIT, Secretary}

\section{U.S. GEOLOGICAL SURVEY \\ Charles G. Groat, Director}

Any use of trade, product, or firm names in this publication is for descriptive purposes only and does not imply endorsement by the U.S. Government.

For additional information contact:

\section{District Chief}

U.S. Geological Survey 10615 S.E. Cherry B lossom Drive

Portland, OR 97216-3159

E-mail: info-or@usgs.gov

Internet: http://oregon.usgs.gov
Copies of this report can be purchased from:

\section{U.S. Geological Survey}

B ranch of Information Services

B ox 25286, Federal Center

Denver, CO 80225-0046 


\section{CONTENTS}

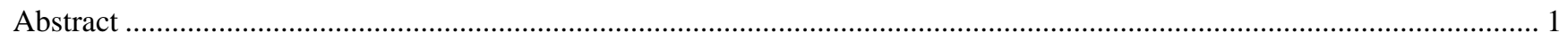

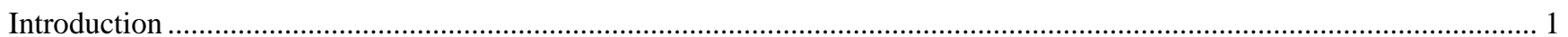

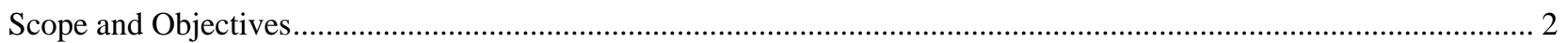

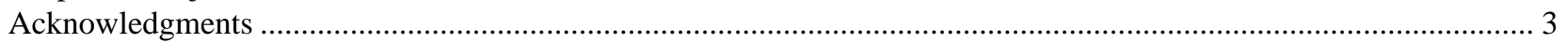

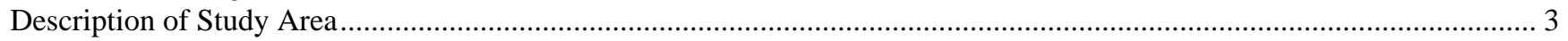

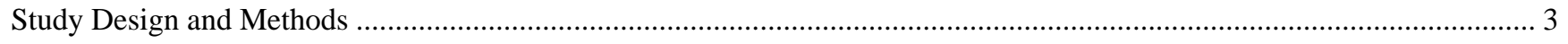

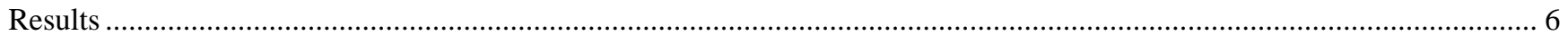

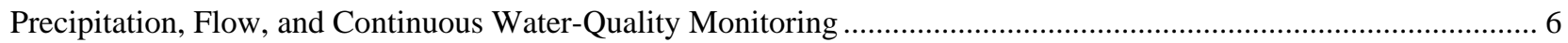

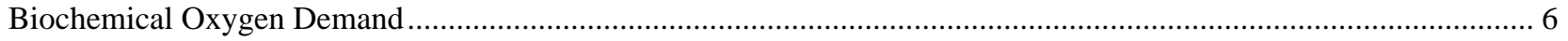

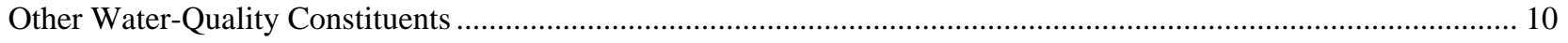

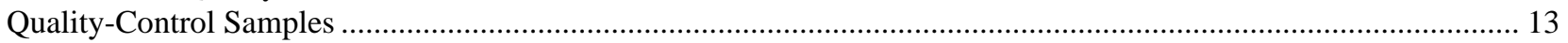

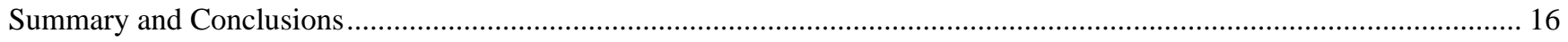

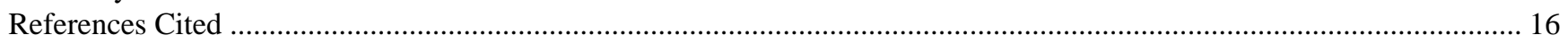

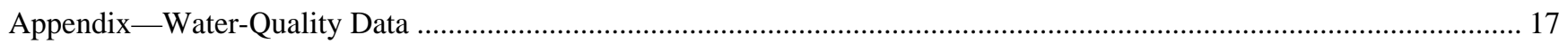

FIGURES

1. Map showing the location of the Bear Creek study area ...........................................................................

2. Graph showing dates of calcium magnesium acetate application and water-quality samples,

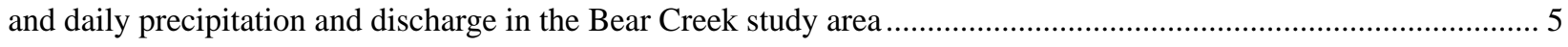

3. Graph showing monthly precipitation at Government Camp, Oregon ............................................................... 6

4. Graphs showing temperature, discharge, precipitation, specific conductance, $\mathrm{pH}$, and dissolved oxygen

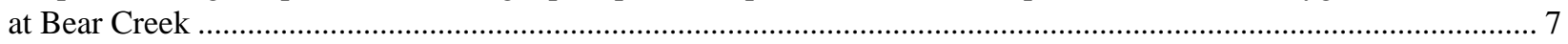

5. Graph showing a typical curve for biochemical oxygen demand in a water-quality sample from

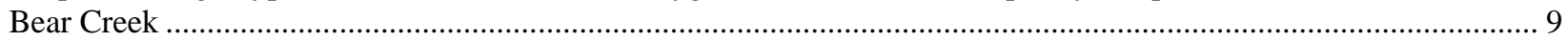

6. Graph showing values for 20-day biochemical oxygen demand of water samples from Bear Creek

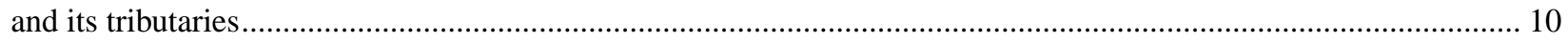

7. Graph showing the biochemical oxygen demand for a 28 milligram per liter calcium magnesium acetate spike....... 12

8. Graph showing the concentration of dissolved calcium in water-quality samples from Bear Creek and its tributaries

9. Graph showing the concentration of dissolved magnesium in water-quality samples from Bear Creek and its tributaries.

\section{TABLES}

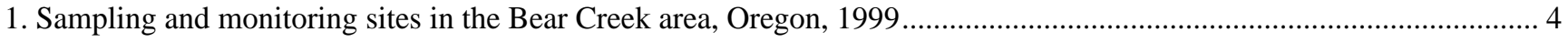

2. Water quality of Bear Creek samples spiked with calcium magnesium acetate ..................................................... 11

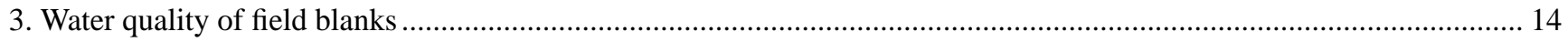

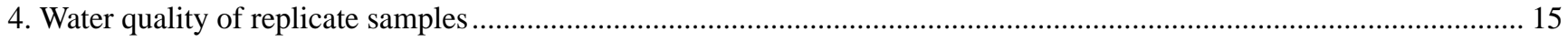


CONVERSION FACTORS AND VERTICAL DATUM

\begin{tabular}{rcl}
\hline Multiply & By & To obtain \\
\hline millimeter $(\mathrm{mm})$ & $\begin{array}{c}0.03937 \\
\text { Volume }\end{array}$ & inch \\
liter $(\mathrm{L})$ & 33.82 & ounce, fluid \\
& Mass & \\
microgram $(\mu \mathrm{g})$ & 0.00000003527 & ounce, avoirdupois \\
milligram $(\mathrm{mg})$ & 0.00003527 & ounce, avoirdupois \\
\hline
\end{tabular}

Temperature in degrees Celsius $\left({ }^{\circ} \mathrm{C}\right)$ may be converted to degrees Fahrenheit $\left({ }^{\circ} \mathrm{F}\right)$ as follows:

$$
{ }^{\circ} \mathrm{F}=1.8^{\circ} \mathrm{C}+32
$$

Sea level: In this report "sea level" refers to the National Geodetic Vertical Datum of 1929 (NGVD of 1929)--a geodetic datum derived from a general adjustment of the first-order level nets of both the United States and Canada, formerly called Sea Level Datum of 1929.

Altitude, as used in this report, refers to distance above or below sea level.

Specific conductance is given in microsiemens per centimeter at 25 degrees Celsius $\left(\mu \mathrm{S} / \mathrm{cm}\right.$ at $\left.25^{\circ} \mathrm{C}\right)$.

Concentrations of chemical constituents in water are given either in milligrams per liter $(\mathrm{mg} / \mathrm{L})$ or micrograms per liter $(\mu \mathrm{g} / \mathrm{L})$. 


\title{
The Effect of Calcium Magnesium Acetate (CMA) Deicing Material on the Water Quality of Bear Creek, Clackamas County, Oregon, 1999
}

\author{
By Dwight Q. Tanner and Tamara M. Wood
}

\section{Abstract}

This report presents the results of a study by the U.S. Geological Survey, done in cooperation with the Oregon Department of Transportation (ODOT), to evaluate the effects of the highway deicing material, calcium magnesium acetate (CMA), on the water quality of Bear Creek, in the Cascade Range of Oregon. ODOT began using CMA (an alternative deicer that has fewer adverse environmental effects than road salt) in the mid-1990s and began this study with the USGS to ensure that there were no unexpected effects on the water quality of Bear Creek. Streamflow, precipitation, dissolved oxygen, $\mathrm{pH}$, specific conductance, and water temperature were measured continuously through the 1998-99 winter.

There was no measurable effect of the application of CMA to Highway 26 on the biochemical oxygen demand (BOD), calcium concentration, or magnesium concentration of Bear Creek and its tributaries. BOD was small in all of the water samples, some of which were collected before CMA application, and some of which were collected after application. Five-day BOD values ranged from 0.1 milligrams per liter to 1.5 milligrams per liter, and 20-day BOD values ranged from 0.2 milligrams per liter to 2.0 milligrams per liter.

Dissolved copper concentrations in a small tributary ditch on the north side of Highway 26 exceeded the U.S. Environmental Protection Agency aquatic life criteria on three occasions. These exceedances were probably not caused by the application of CMA because (1) one of the samples was a background sample (no recent CMA application), and (2) dissolved copper was not detected in Bear Creek water samples to which CMA was added during laboratory experiments.

\section{INTRODUCTION}

Calcium magnesium acetate (CMA) is a useful deicing material for roadways. Its advantages over sodium- and calcium-chloride salts include less corrosiveness to automobiles and to highway materials, and less toxicity to roadside vegetation (Transportation Research Board, 1991). The main disadvantage of CMA is its higher cost, which is 20 times that of salt (Transportation Research Board, 1991, p. 1). The adverse environmental effects of CMA used as an anti-icing material are mainly related to the acetate ion, $\mathrm{C}_{2} \mathrm{H}_{3} \mathrm{O}_{2}^{-}$. Acetate can increase the biochemical oxygen demand (BOD) of streams, causing the depletion of dissolved oxygen (Connolly and others, 1990). The conductivity of the water may increase with the addition of calcium, magnesium, and acetate ions, and the addition of acetate to a stream may increase the alkalinity, and consequently the pH (Horner, 1988).

The effects of CMA on an environmentally sensitive area such as the Cascade Range have not been fully evaluated. In December 1998, the Oregon Department of Transportation (ODOT) entered into a cooperative agreement with the U. S. Geological Survey to measure and evaluate the effects of CMA highway applications on the water quality of Bear Creek, a tributary to the Sandy River located on the western slope of the Cascade Range in Oregon (fig. 1). Bear Creek drains a small watershed that supports a coldwater fishery. It is an ideal site for this study because CMA is applied to Highway 26 at this elevation several times a year as part of ODOT's normal operations. The small size of the creek and the fact that it closely parallels the highway for about 1 mile represent the maximum probable effect for direct runoff of CMA into a receiving stream. Therefore, if the impacts of CMA application on Bear Creek are small, ODOT can proceed with some confidence that impacts on other streams throughout Oregon will probably be small. 


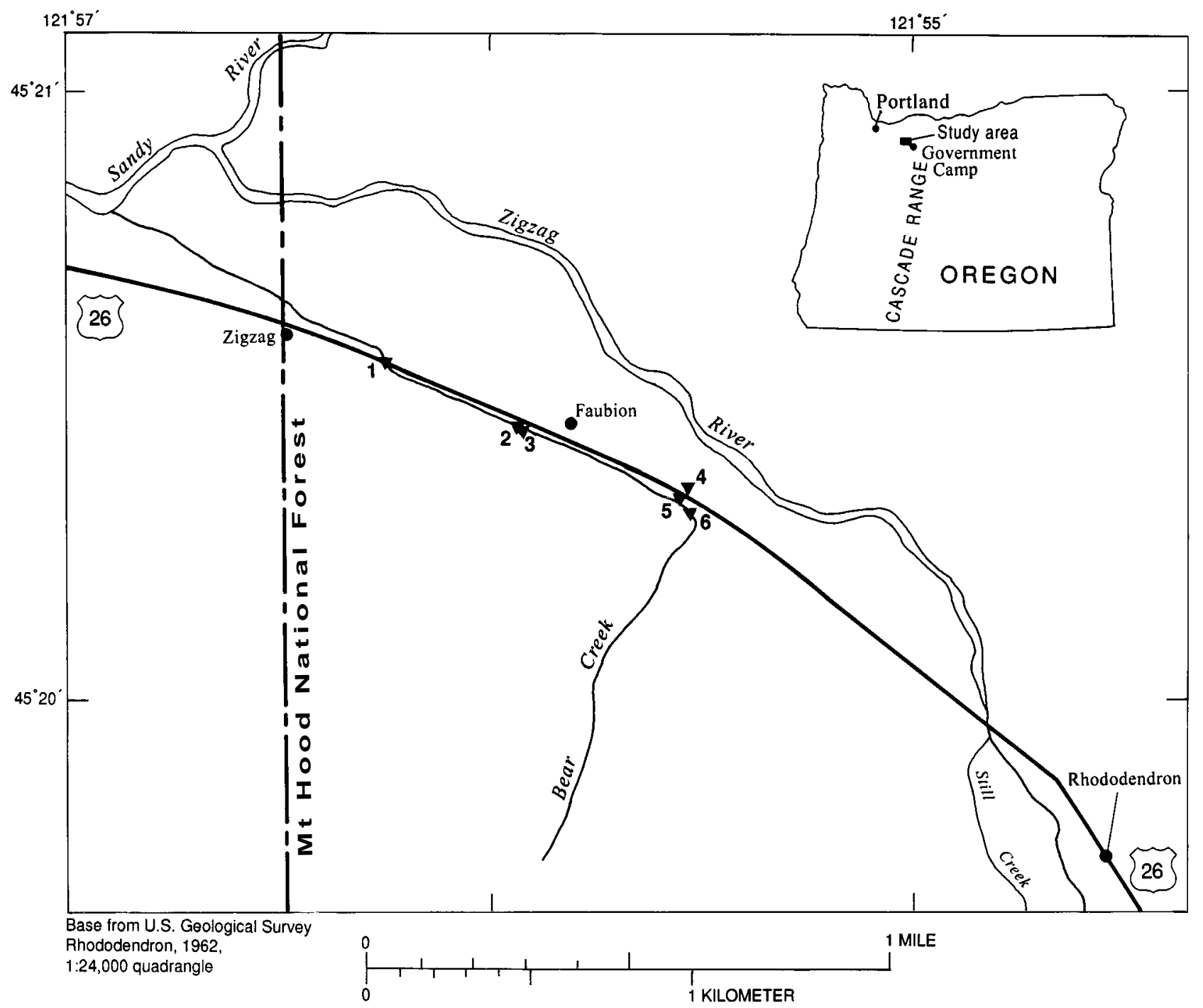

EXPLANATION

${ }^{4} \nabla$ Sampling or monitoring site

1 Bear Creek downstream of West Faubion Loop Bridge (Bear Creek Downstream)

2 Bear Creek neat East Faubion Loop Bridge (Bear Creek Midstream)

3 Bear Creek near Rhododendron (Bear Creek Monitor)

4 Roadside Ditch North of Highway 26 near Faubion (North Ditch)

5 Roadside Ditch South of Highway 26 near Faubion (South Ditch)

6 Bear Creek upstream of East Faubion Loop Bridge (Bear Creek Upstream)

Figure 1. Location of Bear Creek study area.

\section{Scope and Objectives}

The objective of this study was to determine whether the use of CMA under ODOT's normal operating procedures would result in a measurable effect on water quality in Bear Creek. This report contains data and interpretations concerning the environmental effects of CMA on water quality at five stream sites on and near Bear Creek. Waterquality samples were collected both before and shortly after applications of CMA to Highway 26 in January, February, and March 1999. Water-quality samples were analyzed for biochemical oxygen demand, major ions, nutrients, metals, trace elements, dissolved organic carbon, sediment concentration, and (for some samples) chemical oxygen demand. In conjunction with the collection of water samples, measurements were made in the field of dissolved oxygen, $\mathrm{pH}$, specific conductance, water temperature, and barometric pressure. Continuous data were also collected at a water- 
quality monitor and stream gage on Bear Creek. Dissolved oxygen, $\mathrm{pH}$, specific conductance, water temperature, air temperature, and stream stage and velocity were measured.

\section{Acknow ledgments}

The authors express their gratitude to the following individuals and organizations: the Oregon Department of Transportation for cooperative funding and logistical support; Terry Sladky, (ODOT, Sandy Maintenance) for assistance with project coordination; Bernie Bonn (USGS) for ideas concerning experimental design; Jennifer Morace (USGS) for proposal development and loading calculations; and Amy Young (USGS) for assistance in collecting and preparing the samples for analysis. Matt Johnston (USGS) installed and maintained the water-quality monitor, and Greg Olsen (USGS) installed and maintained the stream gage on Bear Creek.

\section{DESCRIPTION OF STUDY AREA}

Bear Creek is a second-order stream with a drainage area of about 1.5 square miles, located in northeastern Clackamas County, Oregon, (fig. 1). The creek flows directly alongside U.S. Highway 26 for approximately 0.6 miles, and over this distance receives runoff directly from the road shoulder. Roadside ditches on both sides of the highway carry runoff from an additional part of Highway 26 and enter Bear Creek at the point where it approaches the roadway.

As well as scattered cabins and residences, the communities of Zigzag, Faubion, and Rhododendron are located in the study area along Highway 26, which is the main transportation corridor along the south flank of Mount Hood. The area attracts many tourists, campers, hikers, skiers, and fisherman. Principal industries in the area are agriculture, forestry, and tourism.

Bear Creek begins in the Mount Hood National Forest at an elevation of approximately 2,800 feet and flows northeasterly for about a mile down a steep ridge. This ridge is composed mostly of the Tertiary volcanic mudflows, lava, and tuff of the Sardine Formation (Peck and others, 1964). At the bottom of the ridge, at an elevation of about 1,520 feet, Bear Creek turns to the northwest and flows along the gentler gradient of the Zigzag River alluvial valley about 1.2 miles to its confluence with the Sandy River. The valley is composed of Quaternary alluvium of silt, sand, and gravel (Peck and others, 1964).

ODOT began using CMA on Highway 26 in about 1995, as an anti-icer to prevent ice formation on the road surface (William Fletcher, Oregon Department of Transportation, written commun., 2000). Highway 26 at the study area does not have any curbs or gutters, so runoff flows directly from the highway into the roadside ditches or into Bear Creek. The average daily traffic for Highway 26 at Rhododendron was about 8,200 vehicles in 1998. The highway surface is asphalt, and no specific best management practices are being used on Highway 26 in the study area (William Fletcher, Oregon Department of Transportation, written commun., 2000).

Because the intent of most of the samples was to detect the delivery of CMA to the streams, the timing of precipitation and runoff was important. Daily rainfall amounts were not available at the sampling sites, but data were available at Government Camp, 9 miles east of the study area at an elevation of 3,980 feet. Annual precipitation amounts at that location and at the study area are similar (Leonard and Collins, 1983, p. 5). Average annual precipitation at Government Camp is 86.82 inches, based on the years 1961-90 (Owenby and Ezell, 1992). Sixty-two percent of this total precipitation occurs during the months of December through April, and much of it as snow. Figure 2 shows a series of storms throughout the study time period, each lasting for several days, with often more than 1 inch of precipitation per day.

\section{STUDY DESIGN AND METHODS}

Five sites were sampled in the Bear Creek area (fig. 1, table 1). Three sites were on Bear Creek: Bear Creek Downstream (sampled only twice), Bear Creek Midstream, and Bear Creek Upstream. Two sites, North Ditch and South Ditch, were on roadside ditches along Highway 26 that are tributaries to Bear Creek. The sites were selected because of their close proximity to Highway 26, where CMA was to be applied by ODOT.

A water-quality monitor and stream-gaging station was operated at Bear Creek near Rhododendron from December 1998 to April 1999. The water-quality monitor utilized a Hydrolab ${ }^{\mathrm{TM}}$ instrument that measured dissolved oxygen, specific conductance, $\mathrm{pH}$, and water temperature every 15 minutes, and logged the data. The stream-gaging equipment was a Unidata Starflow ultrasonic doppler transducer and vented pressure gage, which measured stream velocity and gage height every 30 minutes, and logged the data. All data from the station were transmitted to the USGS office in Portland via a cellular-phone modem. The station was visited about every 3 weeks, or as needed, to calibrate and maintain the equipment.

Field sampling was done either for background conditions (no application within the previous 16 days) or within several days after the application of CMA to Highway 26 and during times of precipitation and runoff (fig. 2). The latter conditions were desirable for the project to give the greatest chance of detecting any environmental effects of CMA application. 
Table 1. Sampling and monitoring sites in the Bear Creek area, Oregon, 1999

\begin{tabular}{|c|c|c|c|c|c|c|}
\hline $\begin{array}{c}\text { Map refer- } \\
\text { ence } \\
\text { number }\end{array}$ & $\begin{array}{l}\text { USGS } \\
\text { site number }\end{array}$ & $\begin{array}{c}\text { Site name } \\
\text { (abbreviated site name) }\end{array}$ & $\begin{array}{l}\text { Bear } \\
\text { Creek } \\
\text { river } \\
\text { mile }\end{array}$ & Latitude & Longitude & Remarks \\
\hline$\overline{1}$ & 452026121554805 & $\begin{array}{l}\text { Bear Creek downstream of } \\
\text { W. Faubion Loop Bridge, } \\
\text { OR } \\
\text { (Bear Creek Downstream) }\end{array}$ & 0.7 & 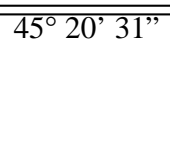 & $121^{\circ} 56^{\prime} 10^{\prime \prime}$ & $\begin{array}{l}\text { Downstream } \\
\text { water-quality } \\
\text { samples }\end{array}$ \\
\hline 2 & 452026121554800 & $\begin{array}{l}\text { Bear Creek near E. Faubion } \\
\text { Loop Bridge, OR } \\
\text { (Bear Creek Midstream) }\end{array}$ & 1.0 & $45^{\circ} 20^{\prime} 26^{\prime \prime}$ & $121^{\circ} 55^{\prime} 48^{\prime \prime}$ & $\begin{array}{l}\text { Midstream } \\
\text { water-quality } \\
\text { samples }\end{array}$ \\
\hline 3 & 14133400 & $\begin{array}{l}\text { Bear Creek near Rhododen- } \\
\text { dron, OR } \\
\text { (Bear Creek Monitor) }\end{array}$ & 1.0 & $45^{\circ} 20^{\prime} 25^{\prime \prime}$ & $121^{\circ} 55^{\prime} 48^{\prime \prime}$ & $\begin{array}{l}\text { Continuous } \\
\text { stage and water } \\
\text { quality }\end{array}$ \\
\hline 4 & 452026121554803 & $\begin{array}{l}\text { Roadside Ditch North of } \\
\text { Highway 26, near Faubion, } \\
\text { OR } \\
\text { (North Ditch) }\end{array}$ & 1.2 & $45^{\circ} 20^{\prime} 22^{\prime \prime}$ & $121^{\circ} 55^{\prime} 34^{\prime \prime}$ & $\begin{array}{l}\text { Possible high- } \\
\text { way runoff }\end{array}$ \\
\hline 5 & 452026121554802 & $\begin{array}{l}\text { Roadside Ditch South of } \\
\text { Highway 26, near Faubion, } \\
\text { OR } \\
\text { (South Ditch) }\end{array}$ & 1.2 & $45^{\circ} 20^{\prime} 20^{\prime \prime}$ & $121^{\circ} 55^{\prime} 34^{\prime \prime}$ & $\begin{array}{l}\text { Possible high- } \\
\text { way runoff }\end{array}$ \\
\hline 6 & 452026121554801 & $\begin{array}{l}\text { Bear Creek upstream of E. } \\
\text { Faubion Loop Bridge, OR } \\
\text { (Bear Creek Upstream) }\end{array}$ & 1.2 & $45^{\circ} 20^{\prime} 20^{\prime \prime}$ & $121^{\circ} 55^{\prime} 34^{\prime \prime}$ & $\begin{array}{l}\text { Upstream } \\
\text { water-quality } \\
\text { samples }\end{array}$ \\
\hline
\end{tabular}

For each sampling trip, if precipitation continued, three water-quality samples were collected approximately 30 minutes apart at Bear Creek Midstream, Bear Creek Upstream, North Ditch, and South Ditch. Samples were collected as grab samples, and plastic gloves were worn during sample collection to avoid contamination of the water-quality samples. Samples for biochemical oxygen demand were collected in triplicate, and 2-chloro-6 (trichloromethyl) pyridine (TCMP) was added to inhibit nitrogenous oxygen demand (American Public Health Association and others, 1998). Concurrent with the collection of each sample, measurements were made in the field of dissolved oxygen, $\mathrm{pH}$, specific conductance, water temperature, air temperature, and barometric pressure.

Water-quality samples were taken to the Portland USGS facility within several hours after sample collection for filtering and preservation. Laboratory analysis of biochemical oxygen demand was done at the Portland USGS facility using methods in American Public Health Association and others (1998). Samples were analyzed for the following at the USGS National Water Quality Laboratory in Denver: major ions, nutrients, metals, trace elements, dissolved organic carbon, and (for some samples) chemical oxygen demand. Sediment concentration and percent sediment finer than 0.062 millimeters were measured for unfiltered water samples at the USGS Cascade Volcano Observatory at Vancouver, Washington. For quality assurance and quality control programs see the website, "http://water.usgs.gov/owq/ quality.html", accessed on February 9, 2000.
Quality control samples comprised about 15 percent of the water-quality samples for the project. Field blanks for biochemical oxygen demand and dissolved organic carbon were prepared by putting commercially available organic-free water through all of the sampling and filtering steps in the field. Field blanks for major ions, trace elements, and nutrients were prepared using inorganic-free water. Replicate samples were prepared by collecting two grab samples from the stream at nearly the same time.

From the field measurements and early laboratory results, it was not certain that any environmental effects of CMA would be observed, so in April, water samples from Bear Creek were used as a matrix to which a CMA solution was added. A number of these "spiked" samples were prepared for analysis, to better understand the suitability and sensitivity of the field and laboratory methods. On April 6, 1999, water samples were obtained from Bear Creek Upstream, Bear Creek Midstream, and Bear Creek Downstream (fig. 1) in 14-liter polyethylene containers. An aliquot of each sample was prepared for analysis and analyzed as the previous samples had been. Another aliquot was used as a matrix into which a CMA solution was micropipetted at the USGS Portland laboratory facility. The CMA solution was obtained from an ODOT application truck. The initial calculations used to determine how much of the CMA solution to add to the environmental samples targeted concentrations of 28, 55, and $83 \mathrm{mg}$ of CMA per liter, based on the assumptions that:

1. The CMA solution is applied to the roadway at 35 gallons/mile. 


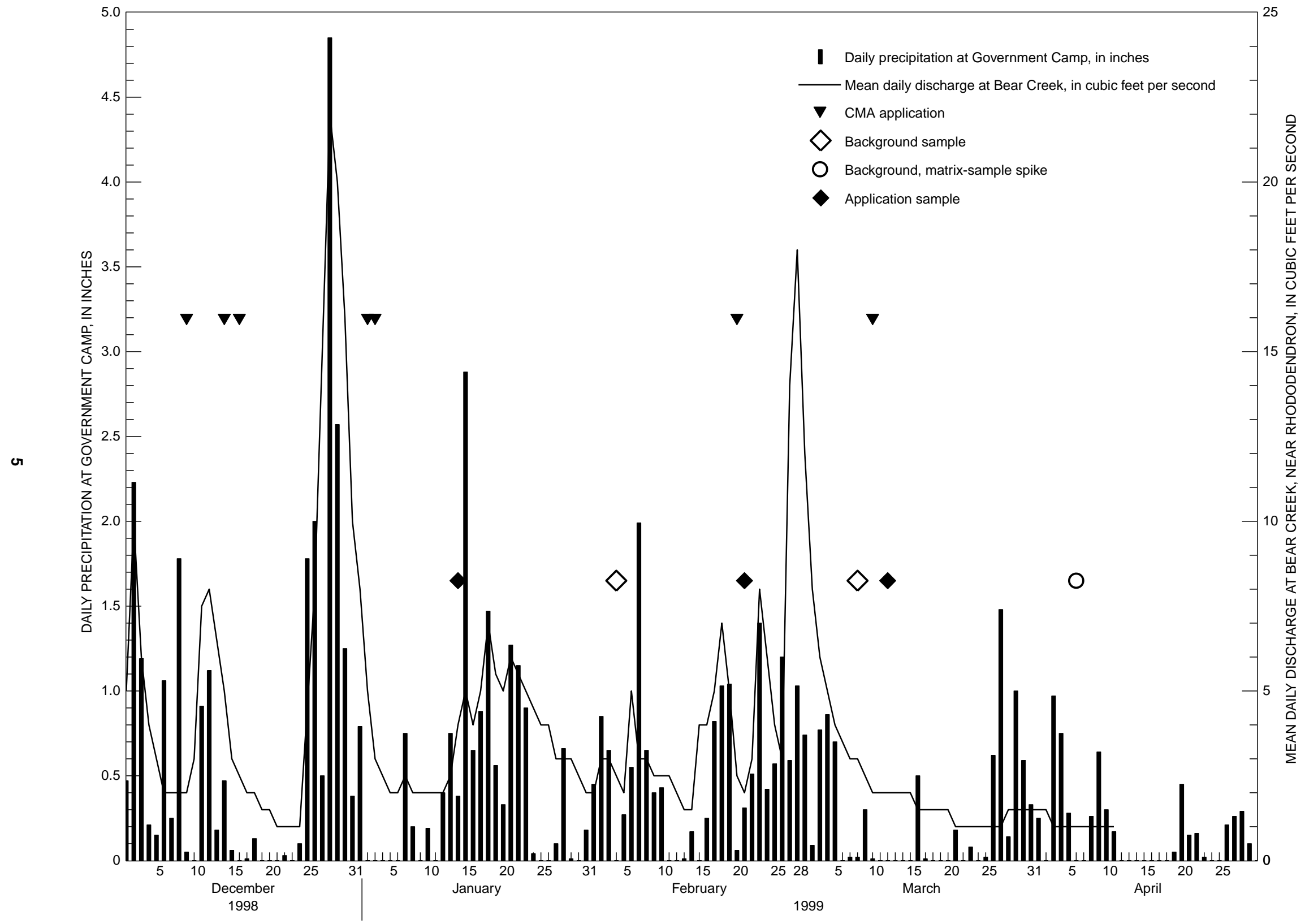

Figure 2. Dates of calcium magnesium acetate application and water-quality samples, and daily precipitation and discharge in Bear Creek study area. 
2. All of the CMA reaches Bear Creek within 1 hour after rain begins.

3. The flow of Bear Creek was 4 cubic feet per second (based on measured flows).

4. Water sampled at Bear Creek Upstream, Midstream, and Downstream has drained from segments of Highway 26 of length $0.25,0.5$, and 0.75 miles, respectively.

To calculate the exact concentration of CMA solution in the spiked environmental samples, the following additional information was used:

1. The solid CMA product was $96 \%$ CMA, which has a molecular weight of $1,471.41$ grams/mole (from the manufacturer, Cryotech, written commun., 1999).

2. The solid CMA product was mixed with water at a dilution factor of 0.33 by weight (Oregon Department of Transportation, written commun., 1999).

The final spike concentrations, therefore, were 28, 55, and $83 \mathrm{mg} / \mathrm{L}$ (milligrams per liter) for Bear Creek Upstream, Midstream, and Downstream, respectively. These spiked samples were prepared and submitted for the same analyses as the other samples. As well as serving as a measure of the effect of higher concentrations of CMA on biochemical oxygen demand (which was the main focus of this study), these spiked samples could also indicate whether there were any other potential contaminants (metals, for example) that could be attributed to CMA application.

\section{RESULTS}

\section{Precipitation, Flow, and Continuous Water-Quality Monitoring}

From December 1998 to March 1999, there were seven applications of CMA to the study area, ranging from 30.2 to 38.8 gallons/mile along Highway 26 (fig. 2). The monthly precipitation average at Government Camp for December, January, and February was higher than the historical average, and for March and April lower than the historical average (fig. 3). The mean daily discharge of Bear Creek near Rhododendron is shown on figure 2. Due to equipment problems at this site, the discharge data are rated as poor quality (5\% of the daily discharges are more than $15 \%$ different from the true value). Nevertheless, the discharge does seem to vary from about 2 or 3 cubic feet per second to 10 or more cubic feet per second after the precipitation events. The precipitation data and the discharge data show a typical wintertime pattern for the study area. These conditions were suitable for studying the possible delivery of CMA to Bear Creek.

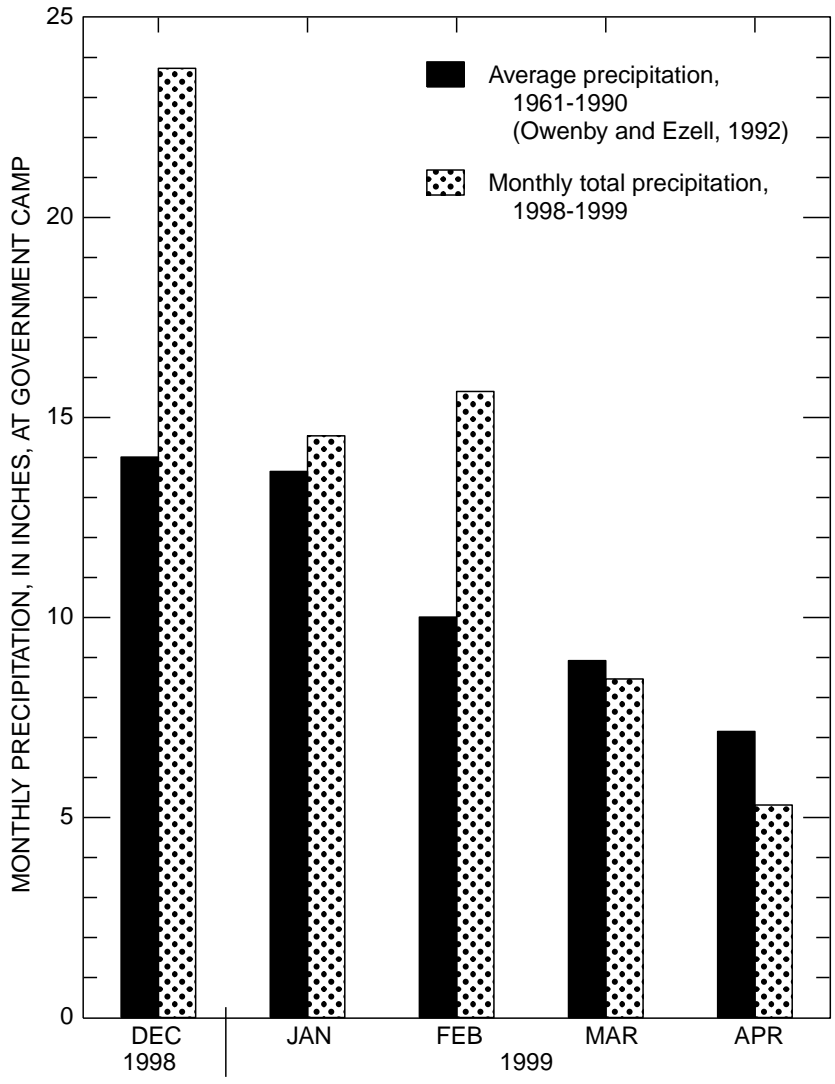

Figure 3. Monthly precipitation at Government Camp, Oregon.

Continuous data for dissolved oxygen, $\mathrm{pH}$, specific conductance, and water temperature did not have noticeable variation related to the application of CMA (fig. 4). Dissolved oxygen concentrations were smallest in late March, a time period with no CMA application, and small precipitation and runoff. $\mathrm{pH}$ and specific conductance did not vary appreciably. The smallest water temperatures were in late December, when precipitation was small.

\section{Biochemical Oxygen Demand}

Biochemical oxygen demand (BOD) is of central importance to this study because one of the possible effects of CMA deicing material on Bear Creek is the increase of BOD caused by the consumption of oxygen by bacteria decomposing acetate, which can act as an organic substrate for bacterial growth (Transportation Research Board, 1991). Other potential sources of BOD in the study area include naturally occurring organic debris. The BOD of a material is the amount of oxygen consumed by aquatic organisms (mainly bacteria) while decomposing and utilizing the organic matter of that material. Changes in BOD can be written as a first-order reaction: 

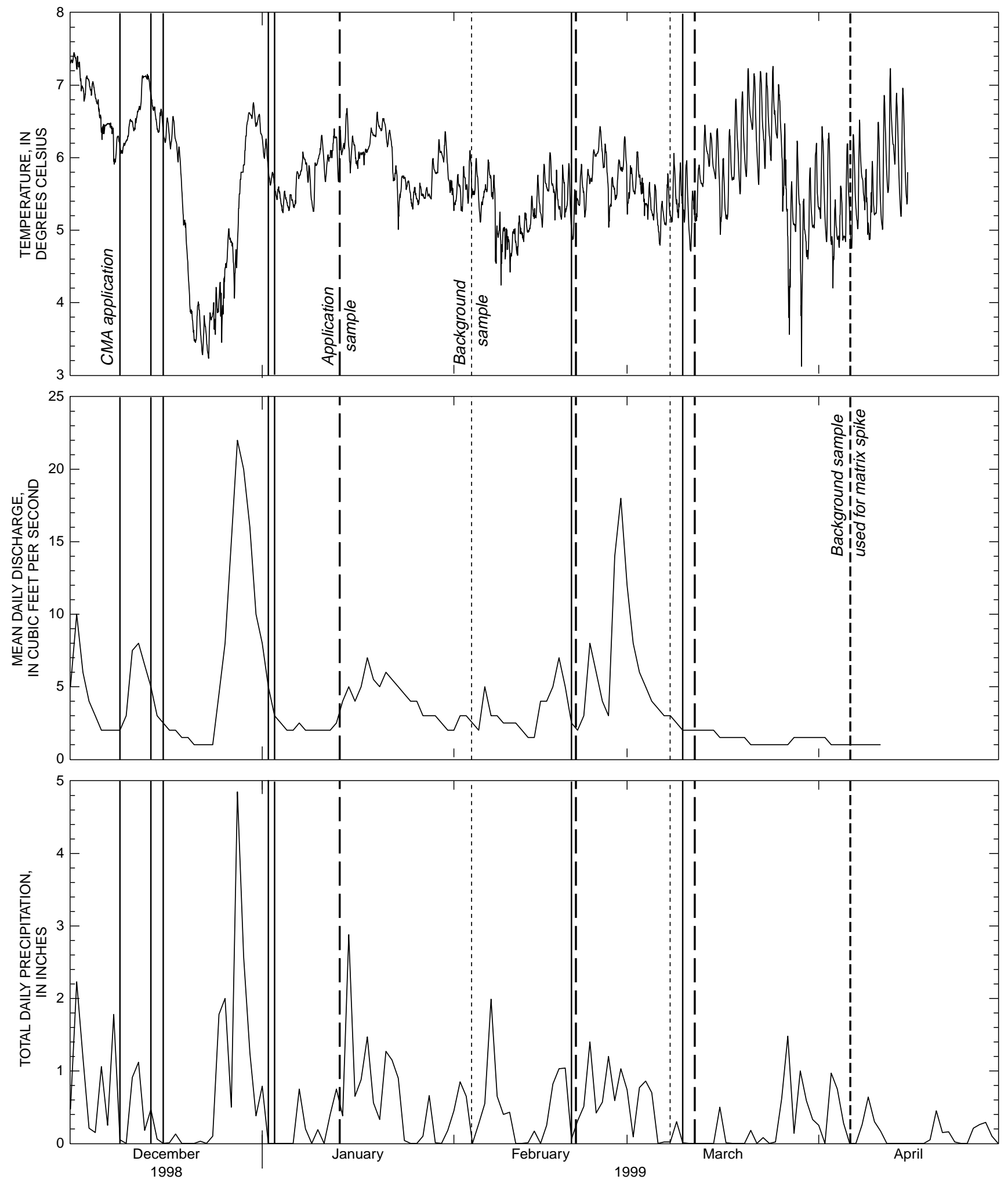

Figure 4. Temperature, discharge, precipitation, specific conductance, $\mathrm{pH}$, and dissolved oxygen at Bear Creek. (Figure continued on next page.) 

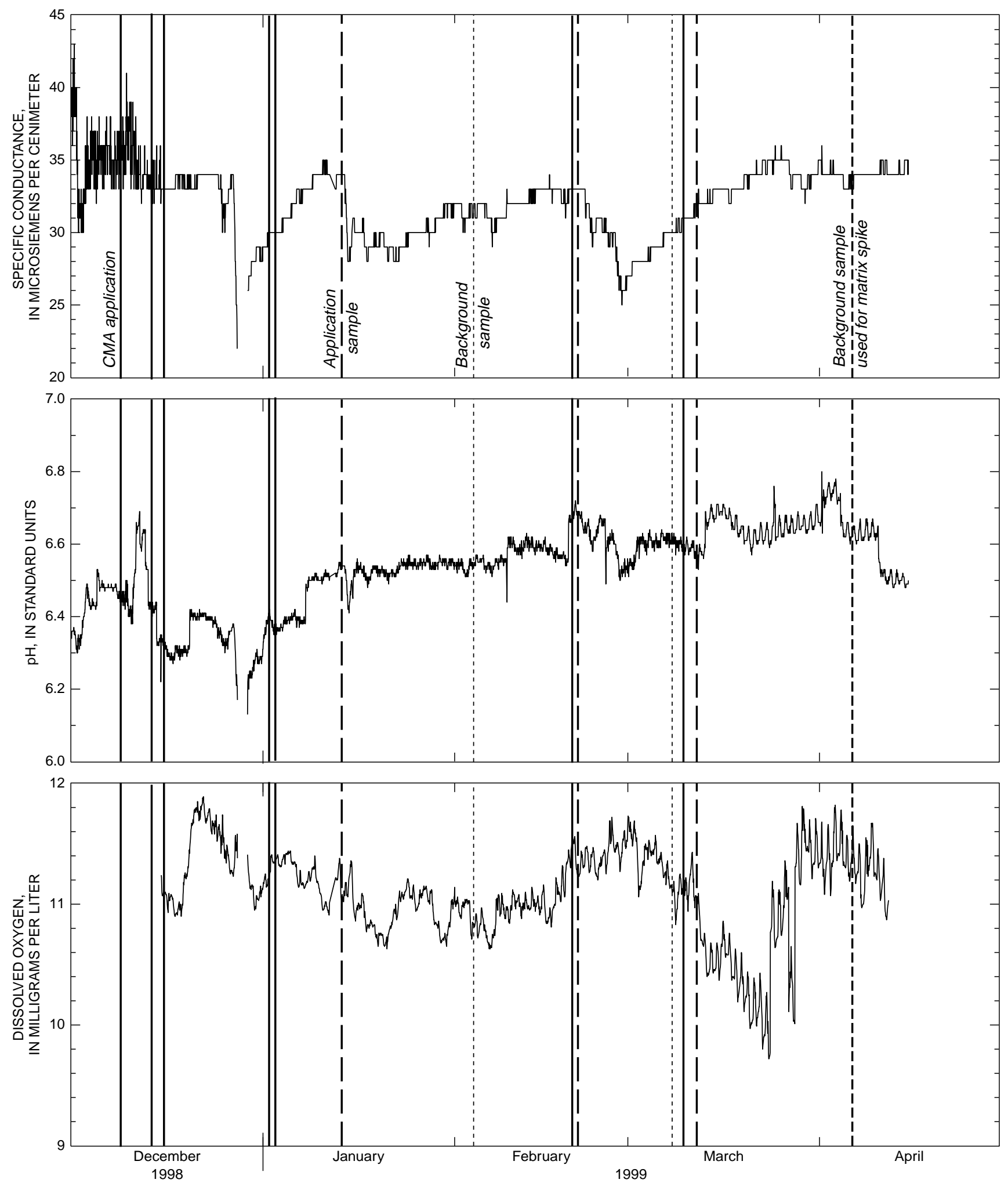

Figure 4. Temperature, discharge, precipitation, specific conductance, $\mathrm{pH}$, and dissolved oxygen at Bear Creek—Continued. 
$d B O D / d t=-k \times B O D$

with a solution of $B O D_{t}=B O D_{u} e^{-k t}$

where

$t=$ elapsed time in days;

$k=\mathrm{BOD}$ decomposition rate at $20^{\circ} \mathrm{C}$ (degrees Celsius), in days $^{-1}$;

$B O D_{u}=$ ultimate $\mathrm{BOD}$, in $\mathrm{mg} / \mathrm{L}$; and

$\mathrm{B} O D_{t}=\mathrm{BOD}$ remaining at time $t$, in $\mathrm{mg} / \mathrm{L}$.

Five-day BOD is the amount of dissolved oxygen consumed (in milligrams per liter) after 5 days of incubation of the water sample, and 20-day BOD is the oxygen consumed after 20 days. If the decomposition of the organic matter is nearly complete after 20 days, the 20-day BOD will be similar in magnitude to the ultimate BOD, the total amount of oxygen that would be consumed if the decomposition of the organic matter was complete.

BOD concentrations measured in environmental samples in this study were low (see appendix). (Five-day BODs and 20-day BODs that are reported here are the means of the three individual bottle values for each sample.) Fiveday BOD values ranged from $0.1 \mathrm{mg} / \mathrm{L}$ to $1.5 \mathrm{mg} / \mathrm{L}$, and 20 day BOD values ranged from $0.2 \mathrm{mg} / \mathrm{L}$ to $2.0 \mathrm{mg} / \mathrm{L}$. The BOD sample bottles were incubated at $20^{\circ} \mathrm{C}$ (following the methods in American Public Health Association and others, 1998), whereas the stream temperatures were about 5 to $6^{\circ} \mathrm{C}$, so actual oxygen consumption by bacteria in the streams would have been smaller than the laboratory values.

Figure 5 shows a BOD curve that is typical of the Bear Creek samples. These data are from a single sample bottle from Bear Creek Midstream taken at 1520 hours on March 12, 1999, after an application of CMA to Highway 26. For this bottle, the 5-day BOD was 0.2 milligrams per liter, the 20-day BOD was 0.4 milligrams per liter, the ultimate BOD (calculated from the equation above) was 0.4 milligrams per liter, and the decomposition rate (base e) was 0.14 units. This figure demonstrates that most of the oxygen demand was exerted in the first 20 days, since the curve flattens out and the 20-day BOD is approximately equal to the ultimate BOD. For 95 percent of the samples, the difference between the 20-day BOD and the calculated ultimate BOD was less than $0.3 \mathrm{mg} / \mathrm{L}$, so the 20-day BOD values cited in the remainder of this report can be considered indicative of the ultimate BOD.

Figure 6 shows all of the 20-day BOD data on a single graph. The data for the Bear Creek sites and South Ditch are closely grouped, with the majority of values being between 0.3 and 0.5 milligrams per liter. There is no apparent difference between the Bear Creek samples taken as background samples and those taken after CMA application. The samples from North Ditch have larger 20-day BODs than any of the other samples, with most values being between 1.0 and 1.2 milligrams per liter. Again, there is not a clear difference between background samples and

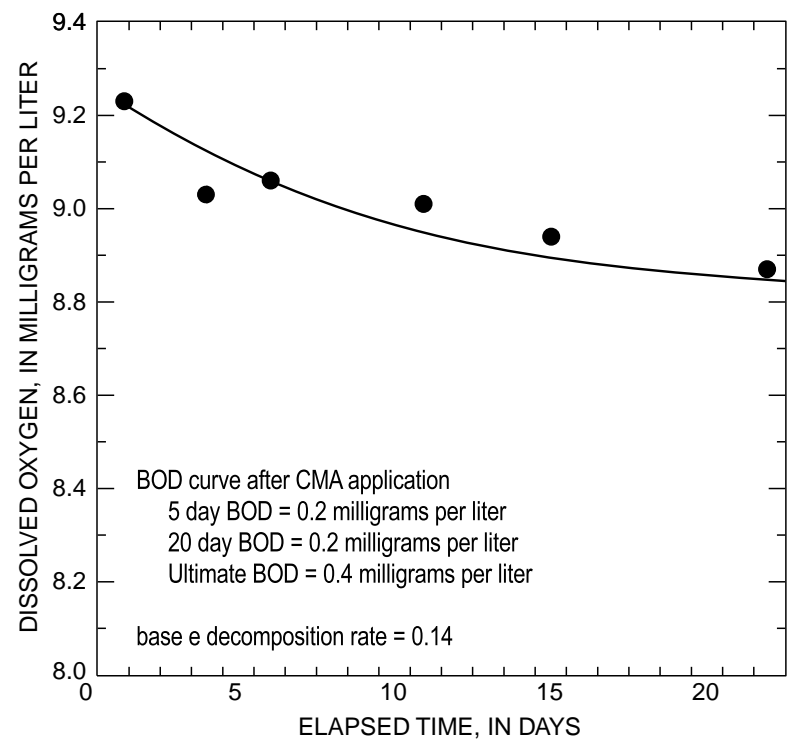

Figure 5. A typical curve for biochemical oxygen demand in a water-quality sample from Bear Creek.

application samples, but there was one outlier of 2.0 milligrams per liter for 20-day BOD after a CMA application. An indication that North Ditch may have additional sources of organic matter is that values for chemical oxygen demand and dissolved organic carbon are larger in North Ditch as well (appendix).

The main purpose of spiking Bear Creek water with CMA solution was to evaluate the effects that larger concentrations of CMA would have on biochemical oxygen demand. The 3 CMA-spiked samples had concentrations of 28,55 , and $83 \mathrm{mg} / \mathrm{L}$ of CMA (table 2). For the $83 \mathrm{ppm}$ CMA spike, it was not possible to determine BOD because virtually all of the oxygen was depleted from the sample bottles by the 10th day after sample collection, and the bacterial population was therefore affected. BOD values for the spiked samples were much larger than those found in Bear Creek and its tributaries. This indicates that the present study would have detected changes in the BOD of Bear Creek if the concentration of CMA had been larger.

Figure 7 shows the BOD plot for a single bottle of the $28 \mathrm{mg} / \mathrm{L}$ CMA spike. (As with all other BOD analyses, three replicate bottles were analyzed, and the mean of the three values was used as the 5- or 20-day BOD value). Dissolved oxygen is shown to have negative values because the bottle was reaerated several times to allow the decomposition to continue. After 20 days, the biochemical oxygen demand for the single bottle was $11.7 \mathrm{mg} / \mathrm{L}$. The bottle only had $8.6 \mathrm{mg} / \mathrm{L}$ at the beginning of the incubation; more oxygen was introduced to the bottle on the 10th and the 17th day. It was not possible to calculate an ultimate BOD value or a decomposition rate from these data because the rate of decomposition did not decrease appreciably over the 20-day incubation period. 


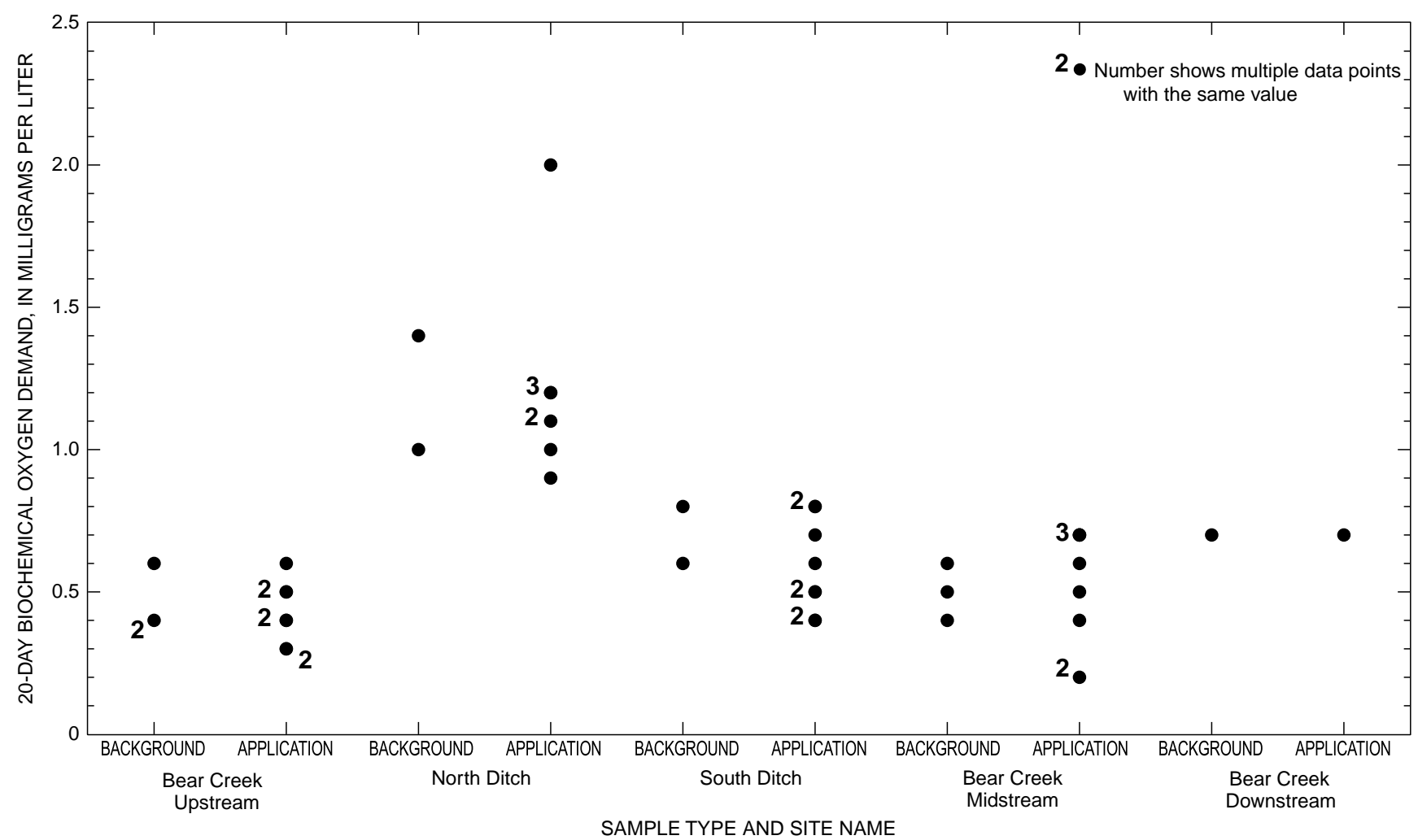

Figure 6. Values for 20-day biochemical oxygen demand of water samples from Bear Creek and its tributaries. (Background samples collected before and application samples collected after the application of calcium magnesium acetate.)

It was possible, however, to use the stoichiometry of the chemical reaction involved to calculate the upper boundary of the amount of oxygen that could have been consumed by the decomposition of the acetate that was introduced to the spike samples. The equation for the mineralization of acetate is:

$$
\mathrm{C}_{2} \mathrm{H}_{3} \mathrm{O}_{2}^{-}+2 \mathrm{O}_{2}+\mathrm{H}^{+}-------->2 \mathrm{CO}_{2}+2 \mathrm{H}_{2} \mathrm{O}
$$

Based on the stoichiometric equation, 1 mole of acetate will consume 2 moles of oxygen if there is sufficient oxygen available. Calculations by Wise and others (1991, p. 73) show that the ultimate BOD based on stoichiometry should be about 62 percent of the CMA concentration. Theoretically, the spike that contained $28 \mathrm{mg} / \mathrm{L}$ of CMA should produce an ultimate BOD of about $24 \mathrm{mg} / \mathrm{L}$, the ultimate BOD for the $55 \mathrm{mg} / \mathrm{L}$ CMA solution should be $48 \mathrm{mg} / \mathrm{L}$ of $\mathrm{O}_{2}$ and for the $83 \mathrm{mg} / \mathrm{L}$ spike, the ultimate BOD should be $72 \mathrm{mg} / \mathrm{L}$ of $\mathrm{O}_{2}$. The results of these calculations are consistent with the data for the $28 \mathrm{mg} / \mathrm{L}$ CMA spike in figure 5 . After 20 days, for this particular bottle, $11.7 \mathrm{mg} / \mathrm{L}$ of $\mathrm{O}_{2}$ was consumed, and the total amount available according to the stoichiometry is $24 \mathrm{mg} / \mathrm{L}$. This means that the acetate in the spiked sample was not yet completely consumed, and indeed the plot of the linear decay shows no indication of change in slope.

\section{Other Water-Quality Constituents}

Calcium and magnesium are alkaline-earth metals that are common and abundant in surface water (Hem, 1989). They are of special interest in this study because they are components of the CMA deicing material. Figure 8 shows the concentration of dissolved calcium in all of the environmental samples. Concentrations in the samples from Bear Creek were closely grouped, ranging from 2.4 milligrams per liter to 3.0 milligrams per liter of dissolved calcium. There was no discernible difference between the background and application samples. Dissolved calcium concentrations were somewhat smaller in North and South Ditches; they ranged from 2.1 to $2.4 \mathrm{mg} / \mathrm{L}$. This difference may be because the ditches had smaller contributing watershed areas than Bear Creek, so the ditches would not have had enough time or opportunity to pick up or adsorb as many calcium ions from the surrounding soils and rocks. For dissolved magnesium, there were only small differences among sites and among background and application samples (fig. 9). All except one sample (1.0 mg/L) had a magnesium concentration between 0.66 and $0.89 \mathrm{mg} / \mathrm{L}$. Magnesium-to-calcium ratios increased linearly from about 0.4 in background waters to 1.0 in the highestconcentration CMA spike. In summary, there was no 
Table 2. Water quality of Bear Creek samples spiked with calcium magnesium acetate [ppm, parts per million; E, estimated; --, no data available]

\begin{tabular}{|c|c|c|c|c|c|c|c|c|c|c|c|}
\hline \multirow{6}{*}{ DATE } & SPE- & $\begin{array}{c}\text { PH } \\
\text { WATER }\end{array}$ & $\begin{array}{l}\text { OXYGEN } \\
\text { DEMAND, }\end{array}$ & $\begin{array}{c}\text { NITRO- } \\
\text { GEN }\end{array}$ & $\begin{array}{l}\text { NITRO- } \\
\text { GEN, AM- }\end{array}$ & $\begin{array}{c}\text { NITRO- } \\
\text { GEN }\end{array}$ & & $\begin{array}{l}\text { PHOS- } \\
\text { PHORUS }\end{array}$ & CARBO & HARD- & \\
\hline & CIFIC & WHOLE & CHEM- & AMMONIA & MONIA + & $\mathrm{NO} 2+\mathrm{NO} 3$ & PHOS- & ORTHO, & ORGANIC & NESS & CALCIUM \\
\hline & $\mathrm{CON}-$ & LAB & ICAL & DIS- & ORGANIC & DIS- & PHORUS & DIS- & DIS- & TOTAL & DIS- \\
\hline & $\begin{array}{l}\text { DUCT- } \\
\text { ANCE }\end{array}$ & $\begin{array}{c}\text { (STAND- } \\
\text { ARD }\end{array}$ & $\begin{array}{l}\text { (HIGH } \\
\text { LEVEL) }\end{array}$ & $\begin{array}{l}\text { SOLVED } \\
\text { (MG/L }\end{array}$ & $\begin{array}{l}\text { TOTAL } \\
\text { (MG/L }\end{array}$ & $\begin{array}{l}\text { SOLVED } \\
\text { (MG/L }\end{array}$ & $\begin{array}{l}\text { TOTAL } \\
\text { (MG/L }\end{array}$ & $\begin{array}{l}\text { SOLVED } \\
\text { (MG/L }\end{array}$ & $\begin{array}{r}\text { SOLVED } \\
\text { (MG/L }\end{array}$ & $\begin{array}{l}\text { (MG / L } \\
\text { AS }\end{array}$ & $\begin{array}{l}\text { SOLVED } \\
\text { (MG/L }\end{array}$ \\
\hline & (US/CM) & UNITS) & (MG/L) & AS N) & A.S N) & A.S N) & AS P) & AS P) & AS C) & (ACO3) & AS CA) \\
\hline & $(00095)$ & $(00403)$ & $(00340)$ & $(00608)$ & $(00625)$ & $(00631)$ & $(00665)$ & $(00671)$ & $(00681)$ & $(00900)$ & $(00915)$ \\
\hline
\end{tabular}

452026121554801 BEAR CREEK UPSTREAM OF E. FAUBION LOOP BRIDGE, OR (LAT $452020 \mathrm{~N}$ LONG $1215534 \mathrm{~W}$ ) APR 1999

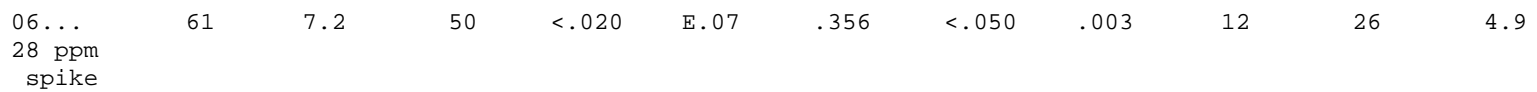

452026121554800 BEAR CREEK NR EAST FAUBION LOOP BRIDGE, OR (LAT $452026 \mathrm{~N}$ LONG 12155 48W)

APR 1999

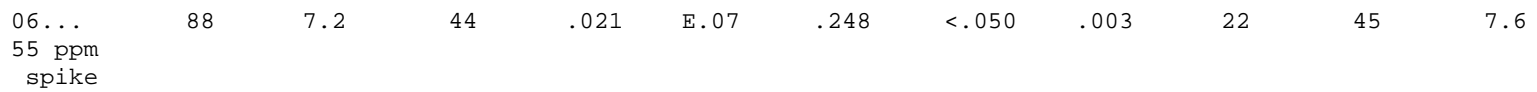

452026121554805 BEAR CREEK DOWNSTREAM OF W FAUBION LOOP BRIDGE, OR (LAT $452031 \mathrm{~N}$ LONG $1215610 \mathrm{~W}$ )

APR 1999

\begin{tabular}{|c|c|c|c|c|c|c|c|c|c|c|c|c|}
\hline $\begin{array}{l}06 \ldots \\
83 \mathrm{ppm} \\
\text { spike }\end{array}$ & 145 & 7.5 & 140 & .023 & E.08 & .197 & $<.050$ & .003 & 26 & 74 & 11 & \\
\hline DATE & $\begin{array}{c}\text { MAGNE- } \\
\text { SIUM, } \\
\text { DIS- } \\
\text { SOLVED } \\
\text { (MG/L } \\
\text { AS MG) } \\
(00925)\end{array}$ & $\begin{array}{c}\text { CADMIUM } \\
\text { DIS- } \\
\text { SOLVED } \\
\text { (UG/L } \\
\text { AS CD) } \\
(01025)\end{array}$ & $\begin{array}{l}\text { CADMIUM } \\
\text { WATER } \\
\text { UNFLTRD } \\
\text { TOTAL } \\
\text { (UG/L } \\
\text { AS CD) } \\
(01027)\end{array}$ & $\begin{array}{l}\text { COPPER, } \\
\text { DIS- } \\
\text { SOLVED } \\
\text { (UG/L } \\
\text { AS CU) } \\
(01040)\end{array}$ & $\begin{array}{c}\text { COPPER, } \\
\text { TOTAL } \\
\text { RECOV- } \\
\text { ERABLE } \\
\text { (UG/L } \\
\text { AS CU) } \\
(01042)\end{array}$ & $\begin{array}{c}\text { LEAD, } \\
\text { DIS- } \\
\text { SOLVED } \\
\text { (UG/L } \\
\text { AS PB) } \\
(01049)\end{array}$ & $\begin{array}{l}\text { LEAD, } \\
\text { TOTAL } \\
\text { RECOV- } \\
\text { ERABLE } \\
\text { (UG/L } \\
\text { AS PB) } \\
(01051)\end{array}$ & $\begin{array}{c}\text { ZINC, } \\
\text { DIS- } \\
\text { SOLVED } \\
\text { (UG/L } \\
\text { AS ZN) } \\
(01090)\end{array}$ & $\begin{array}{l}\text { ZINC, } \\
\text { TOTAL } \\
\text { RECOV- } \\
\text { ERABLE } \\
\text { (UG/L } \\
\text { AS ZN) } \\
(01092)\end{array}$ & $\begin{array}{c}\text { NITRO- } \\
\text { GEN, } \\
\text { AMMONIA } \\
\text { DIS- } \\
\text { SOLVED } \\
\text { (MG/L } \\
\text { AS NH4) } \\
(71846)\end{array}$ & $\begin{array}{l}\text { BOD } \\
\text { OXYGEN } \\
\text { DEMAND, } \\
\text { BIOCHEM } \\
\text { CARBON. } \\
5 \text { DAY } \\
(\text { MG/L) } \\
(80082)\end{array}$ & $\begin{array}{l}\text { OXYGEN } \\
\text { DEMAND, } \\
\text { BIOCHEM } \\
\text { CARBON. } \\
20 \text { DAY } \\
(\text { MG/L) } \\
(80087)\end{array}$ \\
\hline
\end{tabular}

452026121554801 BEAR CREEK UPSTREAM OF E. FAUBION LOOP BRIDGE, OR (LAT $452020 \mathrm{~N}$ LONG $1215534 \mathrm{~W}$ )

APR 1999

$\begin{array}{llllllllllll}06 & \ldots & 3.3 & <1.0 & <1 & <1.0 & <1 & <1.0 & <1 & <20 & <10 & --\end{array}$

452026121554800 BEAR CREEK NR EAST FAUBION LOOP BRIDGE, OR (LAT 4520 26N LONG 12155 48W)

APR 1999

$\begin{array}{lllllllllllllll}06 & \ldots & 6.4 & <1.0 & <1 & <1.0 & <1 & <1.0 & <1 & <20 & 10 & .03 & 2.4 & & \end{array}$

452026121554805 BEAR CREEK DOWNSTREAM OF W FAUBION LOOP BRIDGE, OR (LAT $452031 \mathrm{~N}$ LONG $1215610 \mathrm{~W}$ )

APR 1999

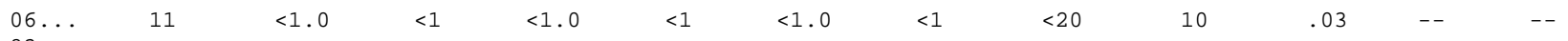

$83 \mathrm{ppm}$ 


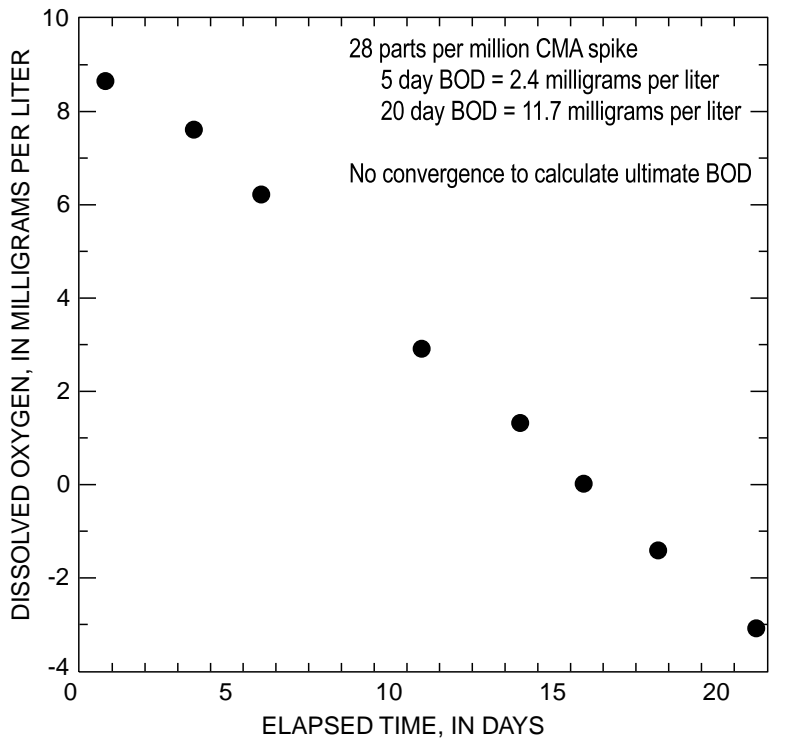

Figure 7. Biochemical oxygen demand (BOD) for a 28 milligram per liter calcium magnesium acetate (CMA) spike.

significant effect of CMA application on the concentrations of dissolved calcium and magnesium.

The minimum detection limits for the dissolved trace elements were relatively large $(0.1 \mathrm{mg} / \mathrm{L}$ for cadmium, copper, and lead; and $20 \mathrm{mg} / \mathrm{L}$ for zinc), so it was not always possible to draw conclusions about differences in trace ele- ment concentrations. There were, however, anomalously high concentrations of dissolved copper in some samples from North Ditch (appendix). The U.S. Environmental Protection Agency (USEPA) aquatic life criteria for trace elements (U.S. Environmental Protection Agency, 1999) are dependent on hardness, and taking that into consideration, the samples for North Ditch exceeded the criteria on February 21, March 8, and March 12 (all three samples). At the hardness levels of 9 to $10 \mathrm{mg} / \mathrm{L}$ of hardness as $\mathrm{CaCO}_{3}$, which were measured for these samples, the USEPA aquatic criterion is a maximum dissolved copper of 1.2 to $1.3 \mathrm{ug} / \mathrm{L}$, respectively. The larger copper concentrations in North Ditch were apparently not due to the use of CMA because the North Ditch sample of March 8 was a background sample (CMA had not been recently applied), and copper was detected at a concentration exceeding the criterion. Another piece of evidence that the dissolved copper detections in North Ditch were not caused by CMA applications is that dissolved copper was not detectable in the CMA-spiked samples (table 2). Copper is a common constituent in highway and urban runoff (Young and others, 1996). The source of copper in North Ditch could have been wastes associated with automobiles and (or) roadway paving materials or geologic sources.

The chemical analyses of the CMA spiked samples also provide significant information concerning trace ele-

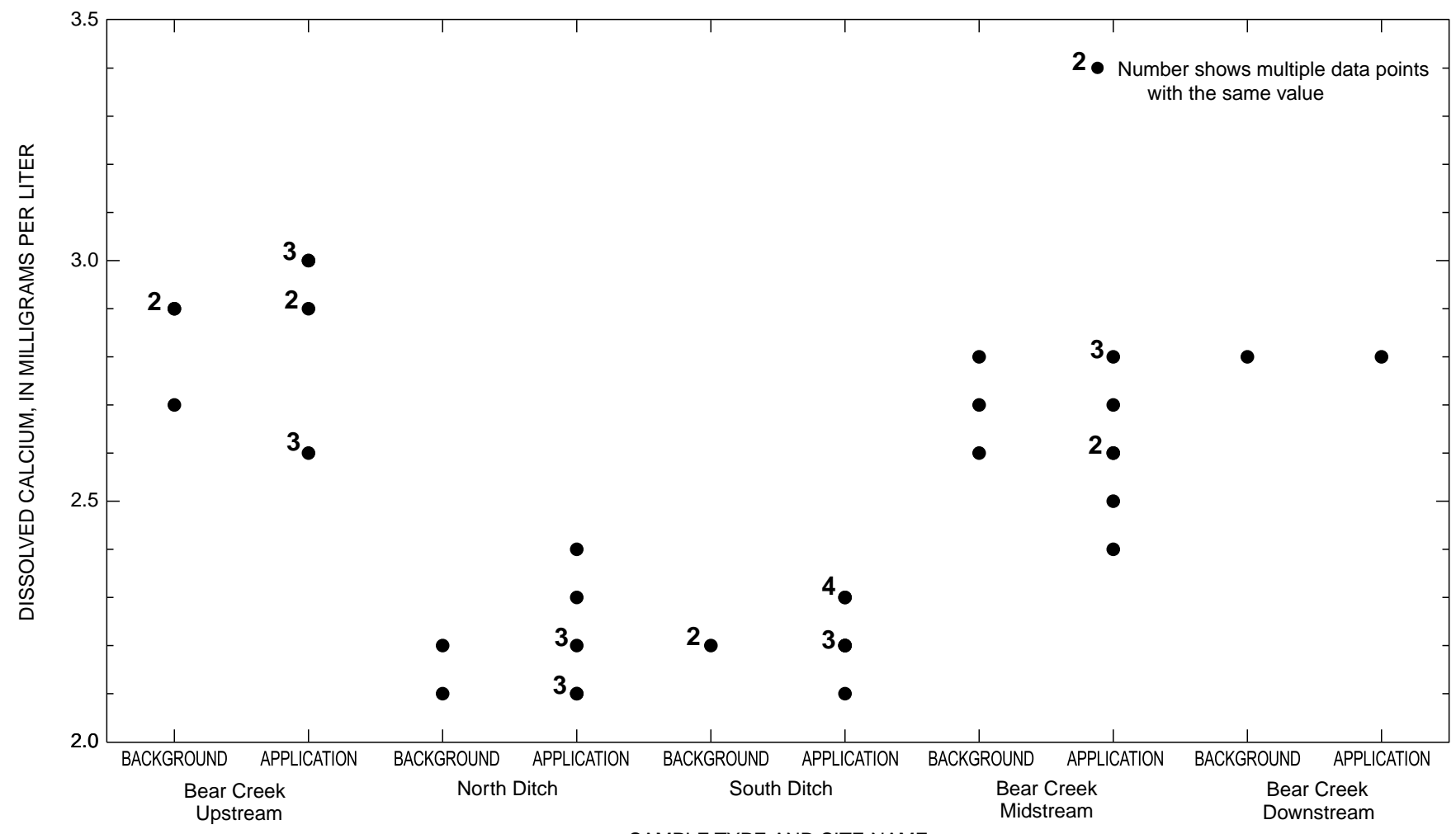

SAMPLE TYPE AND SITE NAME

Figure 8. Concentration of dissolved calcium in water-quality samples from Bear Creek and its tributaries. (Background samples collected before and application samples collected after the application of calcium magnesium acetate.) 


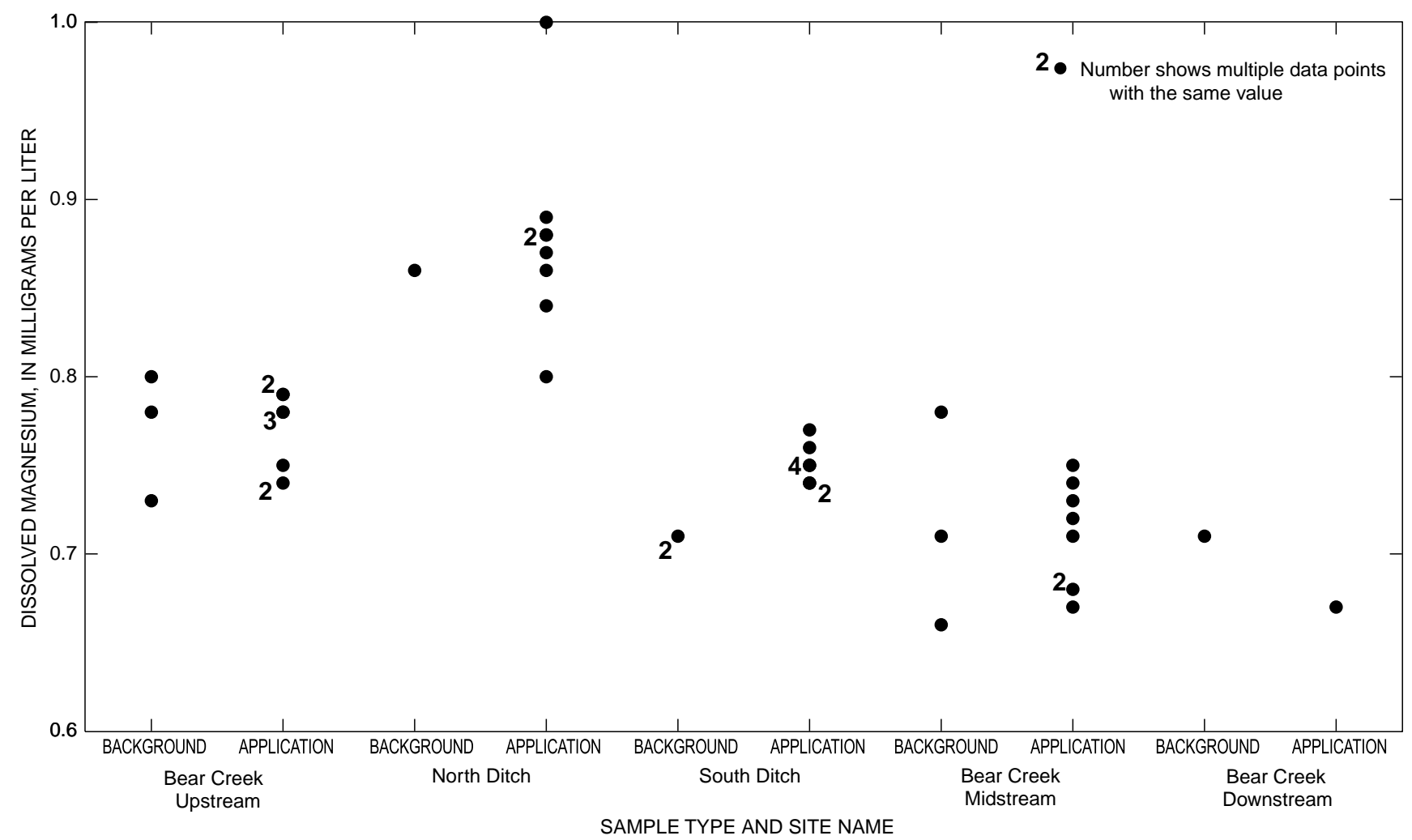

Figure 9. Concentration of dissolved magnesium in water-quality samples from Bear Creek and its tributaries. (Background samples collected before and application samples collected after the application of calcium magnesium acetate.)

ments (table 2). There were no trace elements (cadmium, copper, lead, and zinc) detected in the spiked samples.

\section{Quality-Control Samples}

Field blanks were prepared by subjecting water that was assumed to be free of the target analytes to all of the sampling and filtering steps in the field, as well as the applicable preserving and shipping procedures. The purpose of these samples was to ensure that the cleaning procedures used for the equipment and the sampling and preparation procedures did not introduce a measurable amount of the analytes to the water sample. On two occasions field blanks for biochemical oxygen demand and dissolved organic carbon were prepared by processing commercially available organic-free water in the same manner as the environmental samples. BOD values were very small in these blanks (table 3): 5-day BODs were $0.2 \mathrm{mg} / \mathrm{L}$ and 20-day BODs were 0.2 and $0.3 \mathrm{mg} / \mathrm{L}$, which is in the typical range of measurement error, indicating that the blank water did not acquire a significant amount of oxidizable material from the sampling equipment or procedures. Values for dissolved organic carbon (table 3 ) were $<0.10$ and $0.20 \mathrm{mg} / \mathrm{L}$ as carbon, also indicating that the processing procedures did not introduce organic contaminants.

Four field blanks for major ions, trace elements, and nutrients were prepared using inorganic-free blank water from the USGS Service Unit in Ocala. Results from these field blanks showed only three low-level detections (table 3). The one detection of dissolved nitrate plus nitrite and the two detections of dissolved orthophosphorus were at or near the minimum reporting level for the analyses, so they do not necessarily raise contamination concerns.

Replicate samples were prepared by taking a second grab sample immediately after a routine sample. The purpose of replicate samples was to determine differences in results due to sampling or analytical variability. The two sets of replicate samples showed only small differences that could be attributed to such variability (table 4). The largest difference between a sample and its replicate was at North Ditch on February 21, for ammonia plus total organic nitrogen, with values of 0.13 and $0.56 \mathrm{mg} / \mathrm{L}$, respectively.

Ammonia plus total organic nitrogen concentrations in other samples taken the same day at that site were $0.10 \mathrm{mg} / \mathrm{L}$, so the replicate may have been contaminated. 
Table 3. Water quality of field blanks

[--, no data available]

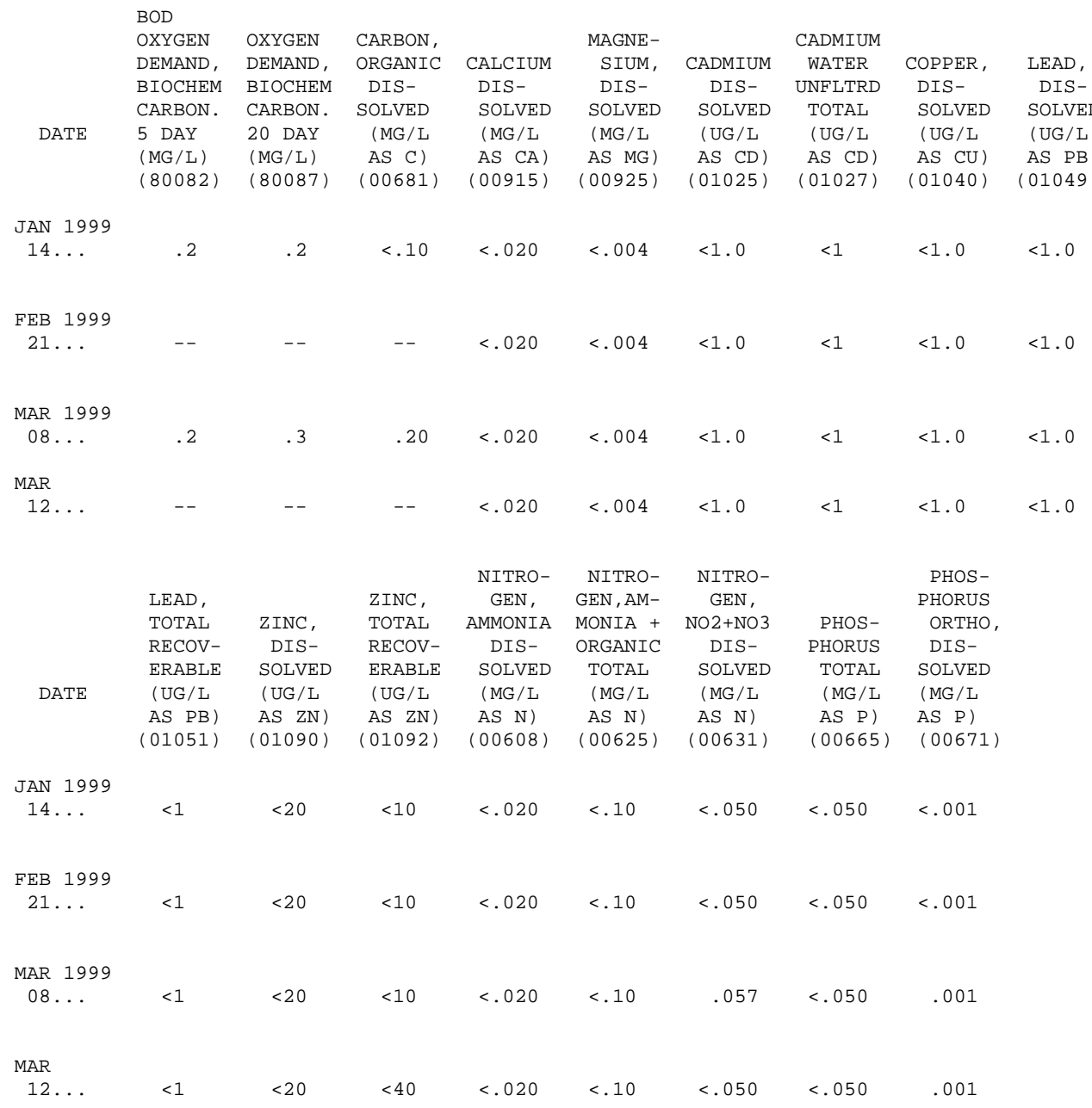


Table 4. Water quality of replicate samples

[--, no data available]

$\begin{array}{cccccccccc} & \text { CARBON, } & & \text { MAGNE- } & & \text { CADMIUM } & & \text { COPPER, } & \text { LEAD, } \\ & \text { ORGANIC } & \text { CALCIUM } & \text { SIUM, } & \text { CADMIUM } & \text { WATER } & \text { COPPER, } & \text { TOTAL } & \text { LEAD, } & \text { TOTAL } \\ & \text { DIS- } & \text { DIS- } & \text { DIS- } & \text { DIS- } & \text { UNFLTRD } & \text { DIS- } & \text { RECOV- } & \text { DIS- } & \text { RECOV- } \\ & \text { SOLVED } & \text { SOLVED } & \text { SOLVED } & \text { SOLVED } & \text { TOTAL } & \text { SOLVED } & \text { ERABLE } & \text { SOLVED } & \text { ERABLE } \\ \text { DATE } & \text { (MG/L } & \text { (MG/L } & \text { (MG/L } & \text { (UG/L } & \text { (UG/L } & \text { (UG/L } & \text { (UG/L } & (\text { UG/L } & \text { (UG/L } \\ & \text { AS C) } & \text { AS CA) } & \text { AS MG) } & \text { AS CD) } & \text { AS CD) } & \text { AS CU) } & \text { AS CU) } & \text { AS PB) } & \text { AS PB) } \\ & (00681) & (00915) & (00925) & (01025) & (01027) & (01040) & (01042) & (01049) & (01051)\end{array}$

452026121554802 ROADSIDE DITCH SOUTH OF HWY 26, NR FAUBION, OR (LAT 452020 LONG 12155 34W)

\begin{tabular}{|c|c|c|c|c|c|c|c|c|c|c|}
\hline Sample & MAR 1999 & & & & & & & & & \\
\hline & $12 \ldots$ & 2.0 & 2.2 & .75 & $<1.0$ & $<1$ & $<1.0$ & $<1$ & $<1.0$ & $<1$ \\
\hline Replicate & $\begin{array}{c}\text { MAR } 1999 \\
12 .\end{array}$ & 2.0 & 2.2 & .77 & $<1,0$ & $<1$ & $<1,0$ & $<1$ & $<1,0$ & $<1$ \\
\hline
\end{tabular}

452026121554803 ROADSIDE DITCH NORTH OF HWY 26, NR FAUBION, OR (LAT $452022 \mathrm{~N}$ LONG $1215534 \mathrm{~W}$ )

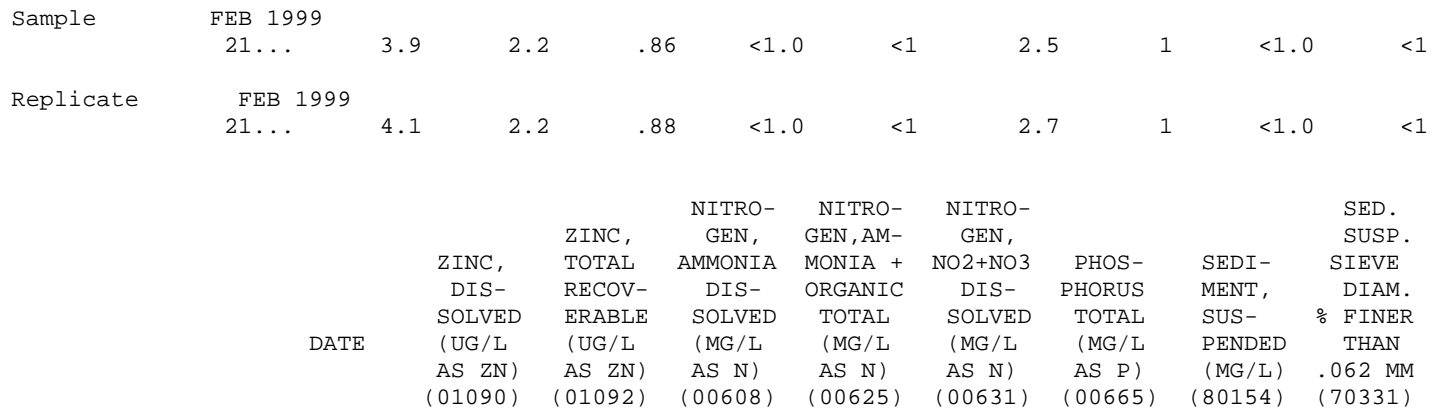

452026121554802 ROADSIDE DITCH SOUTH OF HWY 26, NR FAUBION, OR (LAT $452020 \mathrm{~N}$ LONG $1215534 \mathrm{~W}$ )

\begin{tabular}{|c|c|c|c|c|c|c|c|c|c|}
\hline \multirow[t]{2}{*}{ Sample } & \multirow{2}{*}{\multicolumn{9}{|c|}{$\begin{array}{c}\text { MAR } 1999 \\
12 \ldots\end{array}$}} \\
\hline & & $<20$ & $<10$ & $<.020$ & E.08 & .424 & $<.050$ & 7 & 48 \\
\hline Replicate & MAR 1999 & & & & & & & & \\
\hline & $12 \ldots$ & $<20$ & $<10$ & $<.020$ & E.09 & .417 & $<.050$ & 7 & \\
\hline
\end{tabular}

452026121554803 ROADSIDE DITCH NORTH OF HWY 26, NR FAUBION, OR (LAT $452022 \mathrm{~N}$ LONG $1215534 \mathrm{~W}$ )

\begin{tabular}{|c|c|c|c|c|c|c|c|c|c|}
\hline Sample & $\begin{array}{c}\mathrm{FEB} 1999 \\
21 \ldots\end{array}$ & $<20$ & $<10$ & $<.020$ & .13 & $<.050$ & $<.050$ & 6 & -- \\
\hline Replicate & FEB 1999 & & & & & & & & \\
\hline & $21 \ldots$ & $<20$ & $<10$ & $<.020$ & .56 & $<.050$ & .105 & 2 & \\
\hline
\end{tabular}




\section{SUM MARY AND CONCLUSIONS}

There were no discernible differences in BOD (biochemical oxygen demand), calcium concentration, or magnesium concentration for Bear Creek and its tributaries before and after the application of CMA to U.S. Highway 26. Concentrations of BOD in the water samples were small. Five-day BOD values ranged from $0.1 \mathrm{mg} / \mathrm{L}$ to $1.5 \mathrm{mg} / \mathrm{L}$, and 20-day BOD values ranged from $0.2 \mathrm{mg} / \mathrm{L}$ to $2.0 \mathrm{mg} / \mathrm{L}$. The samples from the North Ditch site had relatively large values for 20-day BOD, chemical oxygen demand, and dissolved organic carbon, possibly due to enrichment from sources of organic matter not related to CMA application.

When CMA solutions were added to Bear Creek water samples to make spiked samples of known concentration, the resulting BODs were so large that even after 20 days of incubation, dissolved oxygen was still being consumed. The ultimate BODs of the spiked samples were calculated stoichiometrically, and they showed agreement with the 20-day BOD values.

Dissolved copper concentrations in North Ditch exceeded the U.S. Environmental Protection Agency aquatic life criterion on several occasions. These exceedances were probably not caused by the application of CMA because (1) one of the samples was a background sample (no recent CMA application), and (2) dissolved copper was not detected in the CMA spikes.

The quality control portion of the study included field blanks and replicate samples. Field blanks for BOD and dissolved organic carbon showed no significant contamination. Field blanks for major ions and trace elements showed no detections, but dissolved nitrate and dissolved orthophosphorus were detected at or near the minimum reporting level. The replicate samples showed small variability.

\section{REFERENCES CITED}

American Public Health Association, American Water Works Association, and Water Environment Federation, 1998, Standard methods for the examination of water and wastewater (20th ed.): Washington, D.C., American Public Health Association, [variously paged].
Connolly, J.P., Paquin, P.R., Mulligan, T.J., Wu, K.B., and Davanzo, L., 1990, Calcium magnesium acetate biodegradation and its impact on surface waters: In Goldman, C.R., and Malyj, G.J., (eds.) The Environmental Impact of Highway Deicing-Proceedings of a symposium held October 13, 1989 at the University of California, Davis Campus: Institute of Ecology, no. 33, p. 140-156.

Hem, J.D., 1989, Study and interpretation of the chemical characteristics of natural water (3rd ed.): U.S. Geological Survey Water-Supply Paper 2254, 263 p.

Horner, R.R., 1988, National Cooperative Highway Research Program Report 305: Environmental monitoring and evaluation of calcium magnesium acetate (CMA): Transportation Research Board, National Research Council, Washington D.C., 27 p.

Leonard, A.R., and Collins, C.A., 1983, Ground water in the northern part of Clackamas County, Oregon: U.S. Geological Survey Open-File Report 80-1049, 85 p.

Owenby, J.R., and Ezell, D.S., 1992, Monthly station normals of temperature, precipitation, and heating and cooling degree days, 1961-90: Climatography of the United States No. 81, National Oceanic and Atmospheric Administration, variously paged.

Peck, D.L., Griggs, A.B. Schlicker, H.G., Wells, F.G., and Dole, H.M., 1964, Geology of the central and northern parts of the Western Cascade Range in Oregon: U.S. Geological Survey Professional Paper 449, 56 p.

Transportation Research Board, 1991, Highway deicingComparing salt and calcium magnesium acetateNational Research Council: Washington D.C., Special Report 235, $170 \mathrm{p}$.

U.S. Environmental Protection Agency, 1999, National Recommended Water Quality Criteria-Correction: EPA 822-Z-99-001, $25 \mathrm{p}$.

Wise, D.L., Levendis, Y.A., and Metghalchi, M., eds, 1991, Calcium magnesium acetate-An emerging bulk chemical for environmental applications-Industrial Chemistry Library_-Volume 2: New York, Elsevier Science Publishers, 219 p.

Young, G.K, Stein, S., Cole, P., Kammer, T., Graziano, F., and Bank, F., 1996, Evaluation and management of highway runoff water quality, 1996: Federal Highway Administration Final Report FHWA-PD-96-032, $480 \mathrm{p}$. 
APPENDIX 
APPENDIX. WATER-QUALITY DATA

[E, Estimated; --, no data available]

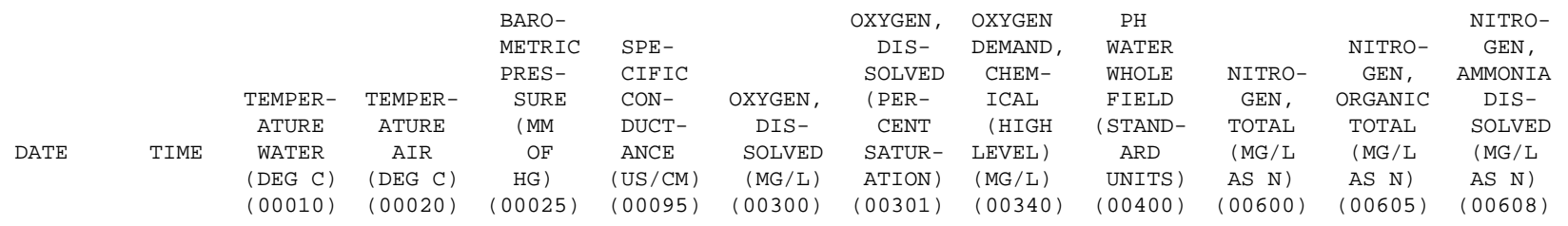

452026121554800 BEAR CREEK NR EAST FAUBION LOOP BRIDGE, OR (LAT 4520 26N LONG 12155 48W)

\begin{tabular}{|c|c|c|c|c|c|c|c|c|c|c|c|c|}
\hline $14 \ldots$ & 1200 & 6.1 & 7.4 & 726 & 39 & 10.4 & 88 & -- & 6.5 & .69 & .14 & .022 \\
\hline $14 \ldots$ & 1500 & 6.6 & 9.1 & 726 & 34 & 10.2 & 87 & -- & 6.5 & .80 & .24 & .021 \\
\hline \multicolumn{13}{|l|}{ FEB } \\
\hline $04 \ldots$ & 0930 & 5.5 & -- & 718 & 29 & 11.6 & 98 & -- & 6.8 & -- & -- & $<.020$ \\
\hline $21 \ldots$ & 1050 & 5.6 & -- & 723 & 37 & 11.4 & 95 & $<10$ & 6.9 & -- & -- & $<.020$ \\
\hline $21 \ldots$ & 1320 & 5.7 & -- & 723 & 37 & 11.4 & 96 & 10 & 6.8 & -- & -- & $<.020$ \\
\hline $21 \ldots$ & 1450 & 5.7 & -- & 723 & 37 & 11.3 & 95 & $<10$ & 6.8 & -- & -- & $<.020$ \\
\hline \multicolumn{13}{|l|}{ MAR } \\
\hline $08 \ldots$ & 1015 & 5.7 & -- & 715 & 29 & 10.9 & 92 & $<10$ & 6.8 & -- & -- & .026 \\
\hline $12 \ldots$ & 1130 & 5.7 & 6.2 & 726 & 30 & 10.9 & 92 & $<10$ & 6.9 & -- & -- & $<.020$ \\
\hline $12 \ldots$ & 1230 & 5.8 & 6.4 & 727 & 30 & 10.7 & 90 & $<10$ & 6.8 & -- & -- & $<.020$ \\
\hline $12 \ldots$ & 1520 & 5.8 & 6.6 & 725 & 30 & 10.6 & 89 & $<10$ & 6.8 & -- & -- & $<.020$ \\
\hline \multicolumn{13}{|l|}{$\mathrm{APR}$} \\
\hline $06 \ldots$ & 1000 & 5.1 & 5.0 & 728 & 40 & 11.2 & 92 & 10 & 7.0 & -- & -- & $<.020$ \\
\hline
\end{tabular}

452026121554801 BEAR CREEK UPSTREAM OF E. FAUBION LOOP BRIDGE, OR (LAT $452020 \mathrm{~N}$ LONG $1215534 \mathrm{~W}$ )

\begin{tabular}{|c|c|c|c|c|c|c|c|c|c|c|c|c|}
\hline $14 \ldots$ & 1115 & 6.0 & 7.4 & 726 & 45 & 9.6 & 81 & -- & 6.5 & .74 & -- & $<.020$ \\
\hline $14 \ldots$ & 1315 & 6.5 & 9.1 & 726 & 12 & 9.8 & 83 & -- & 6.6 & .68 & -- & $<.020$ \\
\hline \multicolumn{13}{|l|}{ FEB } \\
\hline $04 \ldots$ & 0840 & 5.3 & -- & 718 & 31 & 11.6 & 97 & -- & 6.8 & -- & -- & $<.020$ \\
\hline $21 \ldots$ & 1020 & 5.4 & -- & 723 & 39 & 11.6 & 97 & $<10$ & 7.3 & -- & -- & $<.020$ \\
\hline $21 \ldots$ & 1230 & 5.4 & -- & 723 & 39 & 11.5 & 96 & $<10$ & 6.7 & -- & -- & $<.020$ \\
\hline $21 \ldots$ & 1415 & 5.5 & -- & 723 & 27 & 11.4 & 95 & $<10$ & 6.8 & -- & -- & $<.020$ \\
\hline \multicolumn{13}{|l|}{ MAR } \\
\hline $08 \ldots$ & 0910 & 5.2 & 4.6 & 715 & 31 & 11.1 & 94 & $<10$ & 7.1 & -- & -- & $<.020$ \\
\hline $12 \ldots$ & 1040 & 5.3 & 7.4 & 726 & 32 & 11.2 & 93 & $<10$ & 7.0 & -- & -- & $<.020$ \\
\hline $12 \ldots$ & 1210 & 5.3 & 6.3 & 726 & 32 & 11.1 & 92 & $<10$ & 6.8 & -- & -- & $<.020$ \\
\hline $12 \ldots$ & 1450 & 5.5 & 7.9 & 725 & 31 & 11.0 & 92 & $<10$ & 6.7 & -- & -- & $<.020$ \\
\hline \multicolumn{13}{|l|}{ APR } \\
\hline $06 \ldots$ & 0930 & 4.6 & 2.8 & 727 & 39 & 11.4 & 92 & 11 & 7.3 & -- & -- & $<.020$ \\
\hline
\end{tabular}

452026121554802 ROADSIDE DITCH SOUTH OF HWY 26, NR FAUBION, OR (LAT 452020 LONG 1215534 W)

\begin{tabular}{|c|c|c|c|c|c|c|c|c|c|c|c|c|}
\hline $14 \ldots$ & 1045 & 5.5 & 7.4 & 726 & 38 & 9.9 & 83 & -- & 6.1 & .75 & -- & $<.020$ \\
\hline $14 \ldots$ & 1300 & 6.1 & 9.1 & 726 & 34 & 9.9 & 84 & -- & 6.2 & .80 & -- & $<.020$ \\
\hline \multicolumn{13}{|l|}{ FEB } \\
\hline $04 \ldots$ & 0830 & 4.3 & -- & 718 & 25 & 11.3 & 92 & -- & 6.8 & -- & -- & $<.020$ \\
\hline $21 \ldots$ & 1010 & 4.8 & -- & 723 & 33 & 11.1 & 91 & 11 & 7.1 & .65 & -- & $<.020$ \\
\hline $21 \ldots$ & 1240 & 4.8 & -- & 723 & 33 & 11.0 & 91 & $<10$ & 6.7 & -- & -- & $<.020$ \\
\hline $21 \ldots$ & 1430 & 4.9 & -- & 723 & 33 & 11.1 & 91 & $<10$ & 6.8 & -- & -- & $<.020$ \\
\hline \multicolumn{13}{|l|}{ MAR } \\
\hline $08 \ldots$ & 0920 & -- & -- & -- & -- & -- & -- & $<10$ & -- & -- & -- & .030 \\
\hline $12 \ldots$ & 1030 & 4.9 & 7.4 & 726 & 29 & 10.7 & 88 & $<10$ & 6.8 & -- & -- & $<.020$ \\
\hline $12 \ldots$ & 1200 & 5.1 & 6.3 & 726 & 28 & 10.6 & 87 & $<10$ & 6.7 & .53 & -- & $<.020$ \\
\hline $12 \ldots$ & 1425 & 5.2 & 7.9 & 725 & 28 & 10.6 & 88 & $<10$ & 6.6 & -- & -- & $<.020$ \\
\hline
\end{tabular}

452026121554803 ROADSIDE DITCH NORTH OF HWY 26, NR FAUBION, OR (LAT 4520 22N LONG 121 55 34W)

\begin{tabular}{|c|c|c|c|c|c|c|c|c|c|c|c|c|}
\hline $14 \ldots$ & 0945 & 5.8 & 7.4 & 726 & 18 & 7.7 & 65 & -- & 6.1 & .36 & .26 & .021 \\
\hline $14 \ldots$ & 1230 & 6.1 & 9.1 & 726 & 28 & 7.3 & 62 & -- & 6.2 & 1.0 & .19 & .031 \\
\hline \multicolumn{13}{|l|}{$\mathrm{FEB}$} \\
\hline $04 \ldots$ & 0820 & 4.0 & -- & 718 & 26 & 9.0 & 73 & -- & 7.2 & .23 & -- & $<.020$ \\
\hline $21 \ldots$ & 1000 & -- & -- & 723 & -- & -- & -- & $<10$ & -- & -- & -- & $<.020$ \\
\hline $21 \ldots$ & 1250 & -- & -- & 723 & -- & -- & -- & 13 & -- & -- & -- & $<.020$ \\
\hline $21 \ldots$ & 1440 & -- & -- & 723 & -- & -- & -- & 11 & -- & -- & -- & $<.020$ \\
\hline \multicolumn{13}{|l|}{ MAR } \\
\hline $08 \ldots$ & 0930 & 4.7 & 4.6 & 715 & 19 & -- & -- & $<10$ & -- & .20 & -- & $<.020$ \\
\hline $12 \ldots$ & 1020 & 5.3 & 7.4 & 726 & 28 & -- & -- & 11 & -- & -- & -- & $<.020$ \\
\hline $12 \ldots$ & 1150 & 5.5 & 6.3 & 726 & 19 & -- & -- & 18 & -- & -- & -- & $<.020$ \\
\hline $12 \ldots$ & 1400 & 5.5 & 7.9 & 725 & 20 & -- & -- & 15 & -- & -- & -- & $<.020$ \\
\hline
\end{tabular}


APPENDIX. WATER-QUALITY DATA-Continued

\begin{tabular}{|c|c|c|c|c|c|c|c|c|c|c|}
\hline & $\begin{array}{r}\text { NITRO- } \\
\text { GEN, AM- } \\
\text { MONIA + }\end{array}$ & $\begin{array}{c}\text { NITRO- } \\
\text { GEN, } \\
\text { NO2+NO3 }\end{array}$ & PHOS- & $\begin{array}{c}\text { PHOS- } \\
\text { PHORUS } \\
\text { ORTHO, }\end{array}$ & $\begin{array}{l}\text { CARBON, } \\
\text { ORGANIC }\end{array}$ & $\begin{array}{l}\text { HARD- } \\
\text { NESS }\end{array}$ & CALCIUM & $\begin{array}{l}\text { MAGNE- } \\
\text { SIUM, }\end{array}$ & CADMIUM & $\begin{array}{l}\text { CADMIUM } \\
\text { WATER }\end{array}$ \\
\hline & ORGANIC & DIS- & PHORUS & DIS- & DIS- & TOTAL & DIS- & DIS- & DIS- & UNFLTRD \\
\hline & $\begin{array}{l}\text { TOTAL } \\
\text { (MG/L }\end{array}$ & $\begin{array}{l}\text { SOLVED } \\
\text { (MG/L }\end{array}$ & $\begin{array}{l}\text { TOTAL } \\
\text { (MG/L }\end{array}$ & $\begin{array}{l}\text { SOLVED } \\
\text { (MG/L }\end{array}$ & $\begin{array}{r}\text { SOLVED } \\
\text { (MG/L }\end{array}$ & $\begin{array}{l}\text { (MG / L } \\
\text { AS }\end{array}$ & $\begin{array}{l}\text { SOLVED } \\
\text { (MG/L }\end{array}$ & $\begin{array}{l}\text { SOLVED } \\
\text { (MG/L }\end{array}$ & $\begin{array}{l}\text { SOLVED } \\
\text { UG/L }\end{array}$ & $\begin{array}{l}\text { TOTAL } \\
\text { (UG/L }\end{array}$ \\
\hline & AS N) & AS N) & AS P) & AS P) & AS C) & $\mathrm{CACO} 3)$ & AS CA) & AS MG) & AS CD) & AS CD) \\
\hline & $(00625)$ & $(00631)$ & $(00665)$ & $(00671)$ & $(00681)$ & $(00900)$ & $(00915)$ & $(00925)$ & $(01025)$ & (01027) \\
\hline
\end{tabular}

452026121554800 BEAR CREEK NR EAST FAUBION LOOP BRIDGE, OR (LAT 4520 26N LONG 12155 48W)

\begin{tabular}{|c|c|c|c|c|c|c|c|c|c|c|}
\hline $14 \ldots$ & .16 & .532 & $<.050$ & .002 & 1.9 & 10 & 2.7 & .75 & $<1.0$ & $<1$ \\
\hline $\begin{array}{l}14 \ldots \\
F E B\end{array}$ & .26 & .533 & .039 & .002 & 2.4 & 10 & 2.6 & .74 & $<1.0$ & $<1$ \\
\hline $04 \ldots$ & E.08 & .478 & $<.050$ & .002 & 1.2 & 10 & 2.7 & .71 & $<1.0$ & $<1$ \\
\hline $21 \ldots$ & $<.10$ & .434 & $<.050$ & .002 & 1.0 & 10 & 2.8 & .72 & $<1.0$ & $<1$ \\
\hline $21 \ldots$ & E.06 & .455 & $<.050$ & .001 & 1.0 & 10 & 2.8 & .73 & $<1.0$ & $<1$ \\
\hline $21 \ldots$ & $<.10$ & .435 & $<.050$ & .001 & 1.0 & 10 & 2.8 & .71 & $<1.0$ & $<1$ \\
\hline $08 \ldots$ & $<.10$ & .351 & $<.050$ & .002 & 1.1 & 9 & 2.6 & .66 & $<1.0$ & $<1$ \\
\hline $12 \ldots$ & E.08 & .372 & $<.050$ & .002 & 1.0 & 9 & 2.5 & .68 & $<1.0$ & $<1$ \\
\hline $12 \ldots$ & E.06 & .373 & $<.050$ & .002 & 1.0 & 9 & 2.4 & .68 & $<1.0$ & $<1$ \\
\hline $12 \ldots$ & E.08 & .371 & $<.050$ & .003 & 1.0 & 9 & 2.6 & .67 & $<1.0$ & $<1$ \\
\hline APR & & & & & & & & & & \\
\hline $06 \ldots$ & E.07 & .282 & $<.050$ & .002 & 1.1 & 10 & 2.8 & .78 & $<1.0$ & $<1$ \\
\hline
\end{tabular}

452026121554801 BEAR CREEK UPSTREAM OF E. FAUBION LOOP BRIDGE, OR (LAT $452020 \mathrm{~N}$ LONG $1215534 \mathrm{~W}$ )

\begin{tabular}{|c|c|c|c|c|c|c|c|c|c|c|}
\hline $14 \ldots$ & .08 & .659 & $<.050$ & .002 & 1.5 & 11 & 3.0 & .79 & $<1.0$ & $<1$ \\
\hline $14 \ldots$ & .06 & .621 & $<.050$ & .001 & 1.7 & 11 & 3.0 & .78 & $<1.0$ & $<1$ \\
\hline \multicolumn{11}{|l|}{ FEB } \\
\hline $04 \ldots$ & E.05 & .575 & $<.050$ & .002 & 1.1 & 10 & 2.9 & .78 & $<1.0$ & $<1$ \\
\hline $21 \ldots$ & $<.10$ & .522 & $<.050$ & .001 & 1.1 & 11 & 2.9 & .78 & $<1.0$ & $<1$ \\
\hline $21 \ldots$ & E.07 & .543 & $<.050$ & .002 & 1.0 & 11 & 2.9 & .79 & $<1.0$ & $<1$ \\
\hline $21 \ldots$ & $<.10$ & .519 & $<.050$ & .001 & 1.0 & 11 & 3.0 & .78 & $<1.0$ & $<1$ \\
\hline \multicolumn{11}{|l|}{ MAR } \\
\hline $08 \ldots$ & $<.10$ & .392 & $<.050$ & .003 & 1.0 & 10 & 2.7 & .73 & $<1.0$ & $<1$ \\
\hline $12 \ldots$ & E.07 & .448 & $<.050$ & .002 & .90 & 10 & 2.6 & .74 & $<1.0$ & $<1$ \\
\hline $12 \ldots$ & E.08 & .445 & $<.050$ & .002 & .90 & 10 & 2.6 & .74 & $<1.0$ & $<1$ \\
\hline $12 \ldots$ & $<.10$ & .440 & $<.050$ & .003 & 1.0 & 10 & 2.6 & .75 & $<1.0$ & $<1$ \\
\hline \multicolumn{11}{|l|}{ APR } \\
\hline $06 \ldots$ & E.08 & .347 & $<.050$ & .003 & 1.0 & 11 & 2.9 & .80 & $<1.0$ & $<1$ \\
\hline
\end{tabular}

452026121554802 ROADSIDE DITCH SOUTH OF HWY 26, NR FAUBION, OR (LAT $452020 \mathrm{~N}$ LONG $1215534 \mathrm{~W}$ )

\begin{tabular}{|c|c|c|c|c|c|c|c|c|c|c|}
\hline \multicolumn{11}{|c|}{ JAN 1999} \\
\hline $14 \ldots$ & .15 & .606 & $<.050$ & .002 & 3.4 & 9 & 2.3 & .77 & $<1.0$ & $<1$ \\
\hline $14 \ldots$ & .15 & .645 & $<.050$ & .001 & 3.7 & 9 & 2.2 & .74 & $<1.0$ & $<1$ \\
\hline \multicolumn{11}{|l|}{$\mathrm{FEB}$} \\
\hline $04 \ldots$ & E.10 & .621 & $<.050$ & .003 & 2.6 & 8 & 2.2 & .71 & $<1.0$ & $<1$ \\
\hline $21 \ldots$ & .10 & .550 & $<.050$ & .001 & 2.3 & 9 & 2.3 & .75 & $<1.0$ & $<1$ \\
\hline $21 \ldots$ & E.08 & .553 & $<.050$ & .001 & 2.2 & 9 & 2.3 & .74 & $<1.0$ & $<1$ \\
\hline $21 \ldots$ & E.06 & .542 & $<.050$ & .001 & 2.2 & 9 & 2.3 & .75 & $<1.0$ & $<1$ \\
\hline \multicolumn{11}{|l|}{ MAR } \\
\hline $08 \ldots$ & E.08 & .381 & $<.050$ & .002 & 2.1 & 8 & 2.2 & .71 & $<1.0$ & $<1$ \\
\hline $12 \ldots$ & E.08 & .424 & $<.050$ & .001 & 2.0 & 9 & 2.2 & .75 & $<1.0$ & $<1$ \\
\hline $12 \ldots$ & .11 & .419 & $<.050$ & .002 & 2.0 & 8 & 2.1 & .75 & $<1.0$ & $<1$ \\
\hline $12 \ldots$ & E.09 & .411 & $<.050$ & .003 & 2.1 & 9 & 2.2 & .76 & $<1.0$ & $<1$ \\
\hline
\end{tabular}

452026121554803 ROADSIDE DITCH NORTH OF HWY 26, NR FAUBION, OR (LAT $452022 \mathrm{~N}$ LONG 1215534 )

\begin{tabular}{|c|c|c|c|c|c|c|c|c|c|c|}
\hline $14 \ldots$ & .28 & .083 & .032 & .003 & 4.7 & 9 & 2.1 & .84 & $<1.0$ & $<1$ \\
\hline $14 \ldots$ & .23 & .773 & $<.050$ & .003 & 5.0 & 9 & 2.2 & .80 & $<1.0$ & $<1$ \\
\hline \multicolumn{11}{|l|}{ FEB } \\
\hline $04 \ldots$ & .16 & .074 & $<.050$ & .004 & 4.2 & 9 & 2.1 & .86 & $<1.0$ & $<1$ \\
\hline $21 \ldots$ & .10 & $<.050$ & $<.050$ & .003 & 4.0 & 9 & 2.2 & .87 & $<1.0$ & $<1$ \\
\hline $21 \ldots$ & .13 & $<.050$ & $<.050$ & .002 & 3.9 & 9 & 2.2 & .86 & $<1.0$ & $<1$ \\
\hline $21 \ldots$ & E. 10 & $<.05$ & $<.050$ & .003 & 3.8 & 9 & 2.3 & .88 & $<1.0$ & $<1$ \\
\hline \multicolumn{11}{|l|}{ MAR } \\
\hline $08 \ldots$ & .13 & .076 & $<.050$ & .004 & 3.8 & 9 & 2.2 & .86 & $<1.0$ & $<1$ \\
\hline $12 \ldots$ & .16 & $<.050$ & $<.050$ & .003 & 3.7 & 9 & 2.1 & .89 & $<1.0$ & $<1$ \\
\hline $12 \ldots$ & .14 & $<.050$ & $<.050$ & .003 & 3.9 & 9 & 2.1 & .88 & $<1.0$ & $<1$ \\
\hline $12 \ldots$ & .19 & $<.050$ & $<.050$ & .003 & 4.2 & 10 & 2.4 & 1.0 & $<1.0$ & $<1$ \\
\hline
\end{tabular}


APPENDIX. WATER-QUALITY DATA-Continued

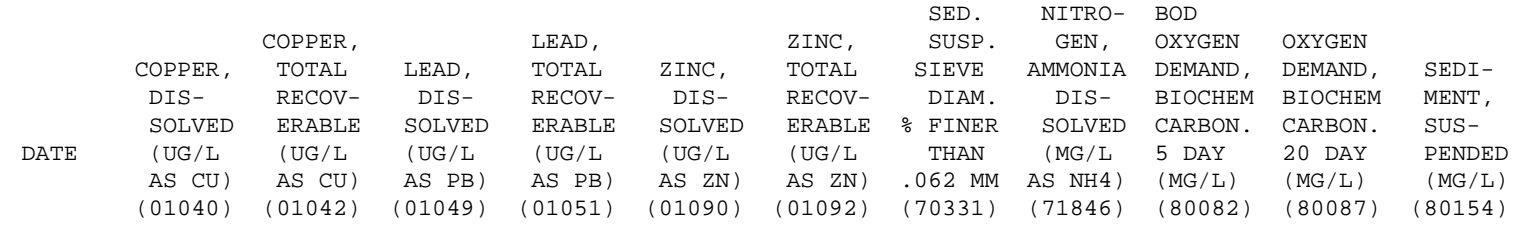

452026121554800 BEAR CREEK NR EAST FAUBION LOOP BRIDGE, OR (LAT 4520 26N LONG 12155 48W)

\begin{tabular}{|c|c|c|c|c|c|c|c|c|c|c|c|}
\hline $14 \ldots$ & $<1.0$ & 1 & $<1.0$ & $<1$ & $<20$ & $<10$ & -- & .03 & .4 & .7 & -- \\
\hline $14 \ldots$ & $<1.0$ & 1 & $<1.0$ & 1 & $<20$ & $<10$ & 84 & .03 & .3 & .6 & 24 \\
\hline \multicolumn{12}{|l|}{ FEB } \\
\hline $04 \ldots$ & $<1.0$ & $<1$ & $<1.0$ & $<1$ & $<20$ & $<10$ & 50 & -- & .3 & .4 & 0 \\
\hline $21 \ldots$ & 1.3 & $<1$ & $<1.0$ & $<1$ & $<20$ & $<10$ & -- & -- & .3 & .7 & -- \\
\hline $21 \ldots$ & $<1.0$ & $<1$ & $<1.0$ & $<1$ & $<20$ & $<10$ & -- & -- & .5 & .5 & -- \\
\hline $21 \ldots$ & $<1.0$ & $<1$ & $<1.0$ & $<1$ & $<20$ & $<10$ & -- & -- & .3 & .7 & 0 \\
\hline \multicolumn{12}{|l|}{ MAR } \\
\hline $08 \ldots$ & $<1.0$ & $<1$ & $<1.0$ & $<1$ & $<20$ & $<10$ & 66 & .03 & .3 & .5 & 8 \\
\hline $12 \ldots$ & $<1.0$ & $<1$ & $<1.0$ & $<1$ & $<20$ & $<10$ & 64 & -- & .1 & .2 & 8 \\
\hline $12 \ldots$ & 1.1 & $<1$ & $<1.0$ & $<1$ & $<20$ & $<10$ & 52 & -- & .1 & .2 & 5 \\
\hline $12 \ldots$ & $<1.0$ & $<1$ & $<1.0$ & $<1$ & $<20$ & $<10$ & 58 & -- & .3 & .4 & 4 \\
\hline \multicolumn{12}{|l|}{ APR } \\
\hline $06 \ldots$ & $<1.0$ & $<1$ & $<1.0$ & $<1$ & $<20$ & $<10$ & 17 & -- & .2 & .6 & 2 \\
\hline
\end{tabular}

452026121554801 BEAR CREEK UPSTREAM OF E. FAUBION LOOP BRIDGE, OR (LAT $452020 \mathrm{~N}$ LONG $1215534 \mathrm{~W}$ )

\begin{tabular}{|c|c|c|c|c|c|c|c|c|c|c|c|}
\hline $14 \ldots$ & $<1.0$ & $<1$ & $<1.0$ & $<1$ & $<20$ & $<10$ & 100 & -- & .3 & .4 & 1 \\
\hline $14 \ldots$ & $<1.0$ & $<1$ & $<1.0$ & $<1$ & $<20$ & $<10$ & -- & -- & .2 & .3 & -- \\
\hline \multicolumn{12}{|l|}{ FEB } \\
\hline $04 \ldots$ & $<1.0$ & $<1$ & $<1.0$ & $<1$ & $<20$ & $<10$ & -- & -- & .2 & .4 & 0 \\
\hline $21 \ldots$ & $<1.0$ & $<1$ & $<1.0$ & $<1$ & $<20$ & $<10$ & -- & -- & .3 & .5 & 0 \\
\hline $21 \ldots$ & $<1.0$ & $<1$ & $<1.0$ & $<1$ & $<20$ & $<10$ & -- & -- & .3 & .5 & -- \\
\hline $21 \ldots$ & $<1.0$ & $<1$ & $<1.0$ & $<1$ & $<20$ & $<10$ & -- & -- & .3 & .6 & 0 \\
\hline \multicolumn{12}{|l|}{ MAR } \\
\hline $08 \ldots$ & $<1.0$ & $<1$ & $<1.0$ & $<1$ & $<20$ & $<10$ & 50 & -- & .3 & .4 & 4 \\
\hline $12 \ldots$ & 2.0 & $<1$ & $<1.0$ & $<1$ & $<20$ & $<10$ & 80 & -- & .2 & .3 & 3 \\
\hline $12 \ldots$ & $<1.0$ & $<1$ & $<1.0$ & $<1$ & $<20$ & $<10$ & 65 & -- & .3 & .4 & 9 \\
\hline $12 \ldots$ & $<1.0$ & $<1$ & $<1.0$ & $<1$ & $<20$ & $<10$ & 50 & -- & .5 & .5 & 5 \\
\hline \multicolumn{12}{|l|}{$\mathrm{APR}$} \\
\hline $06 \ldots$ & $<1.0$ & $<1$ & $<1.0$ & $<1$ & $<20$ & $<10$ & 11 & -- & .2 & .6 & 2 \\
\hline
\end{tabular}

452026121554802 ROADSIDE DITCH SOUTH OF HWY 26, NR FAUBION, OR (LAT $452020 \mathrm{~N}$ LONG $1215534 \mathrm{~W}$ )

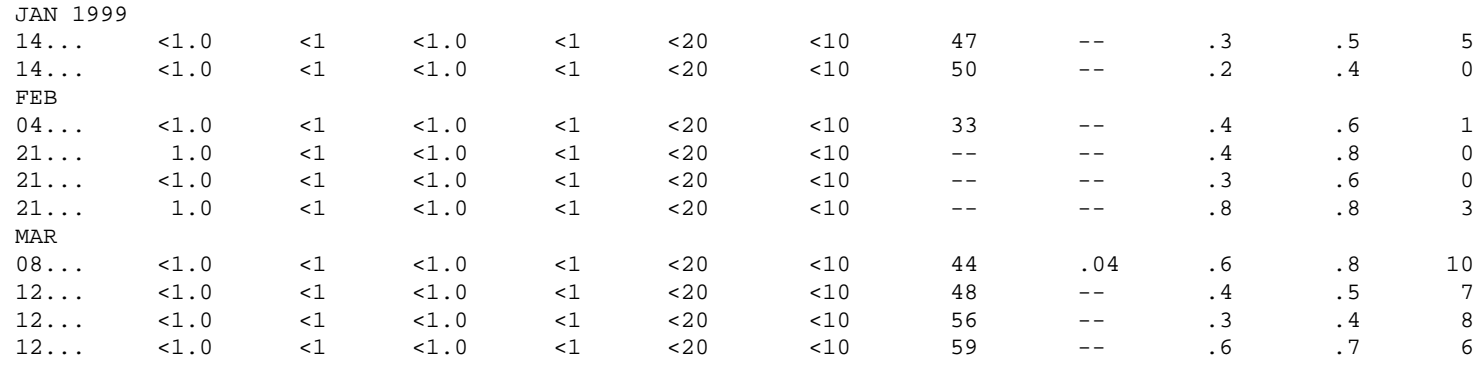

452026121554803 ROADSIDE DITCH NORTH OF HWY 26, NR FAUBION, OR (LAT $452022 \mathrm{~N}$ LONG $1215534 \mathrm{~W}$ )

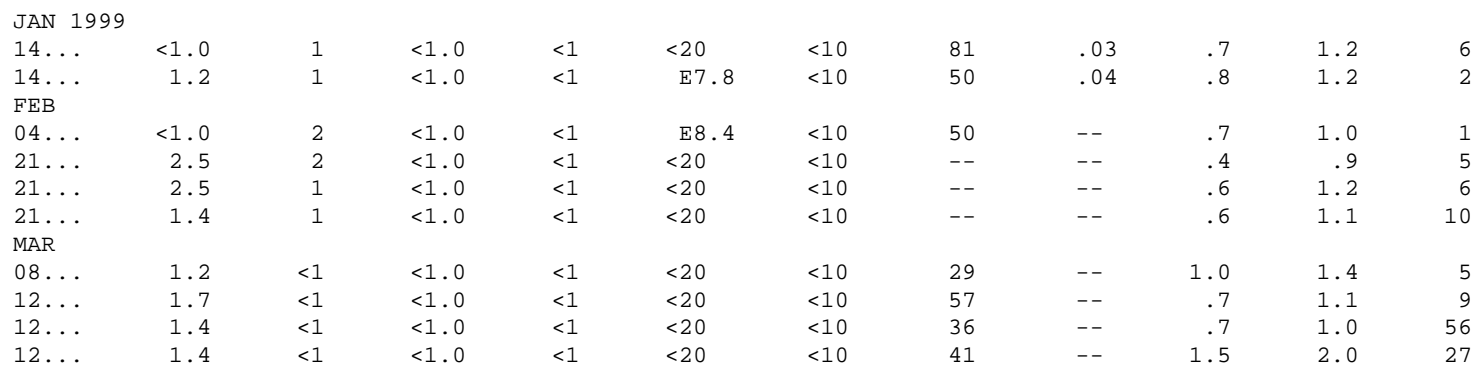


APPENDIX. WATER-QUALITY DATA-Continued

\begin{tabular}{|c|c|c|c|c|c|c|c|c|c|c|c|}
\hline & & & & $\begin{array}{l}\text { BARO- } \\
\text { METRIC } \\
\text { PRES- }\end{array}$ & $\begin{array}{l}\text { SPE- } \\
\text { CIFIC }\end{array}$ & & $\begin{array}{c}\text { OXYGEN, } \\
\text { DIS- } \\
\text { SOLVED }\end{array}$ & $\begin{array}{c}\text { OXYGEN } \\
\text { DEMAND, } \\
\text { CHEM- }\end{array}$ & $\begin{array}{c}\text { PH } \\
\text { WATER } \\
\text { WHOLE }\end{array}$ & $\begin{array}{c}\text { NITRO- } \\
\text { GEN, } \\
\text { AMMONIA }\end{array}$ & $\begin{array}{l}\text { NITRO- } \\
\text { GEN, AM- } \\
\text { MONIA + }\end{array}$ \\
\hline ATE & TIME & $\begin{array}{c}\text { TEMPER- } \\
\text { ATURE } \\
\text { WATER } \\
(\text { DEG C) } \\
(00010)\end{array}$ & $\begin{array}{c}\text { TEMPER- } \\
\text { ATURE } \\
\text { AIR } \\
(\text { DEG C) } \\
(00020)\end{array}$ & $\begin{array}{c}\text { SURE } \\
\text { (MM } \\
\text { OF } \\
\text { HG) } \\
(00025)\end{array}$ & $\begin{array}{l}\text { CON- } \\
\text { DUCT- } \\
\text { ANCE } \\
(\text { US /CM) } \\
(00095)\end{array}$ & $\begin{array}{c}\text { OXYGEN, } \\
\text { DIS- } \\
\text { SOLVED } \\
(\text { MG/L) } \\
(00300)\end{array}$ & $\begin{array}{c}\text { (PER- } \\
\text { CENT } \\
\text { SATUR- } \\
\text { ATION) } \\
(00301)\end{array}$ & $\begin{array}{c}\text { ICAL } \\
(H I G H \\
\text { LEVEL) } \\
(\mathrm{MG} / \mathrm{L}) \\
(00340)\end{array}$ & $\begin{array}{c}\text { FIELD } \\
\text { (STAND- } \\
\text { ARD } \\
\text { UNITS) } \\
(00400)\end{array}$ & $\begin{array}{c}\text { DIS- } \\
\text { SOLVED } \\
(M G / L \\
\text { AS N) } \\
(00608)\end{array}$ & $\begin{array}{c}\text { ORGANIC } \\
\text { TOTAL } \\
(M G / L \\
\text { AS N) } \\
(00625)\end{array}$ \\
\hline
\end{tabular}

452026121554805 BEAR CREEK DOWNSTREAM OF W FAUBION LOOP BRIDGE, OR (LAT $452031 \mathrm{~N}$ LONG 12156 1OW)

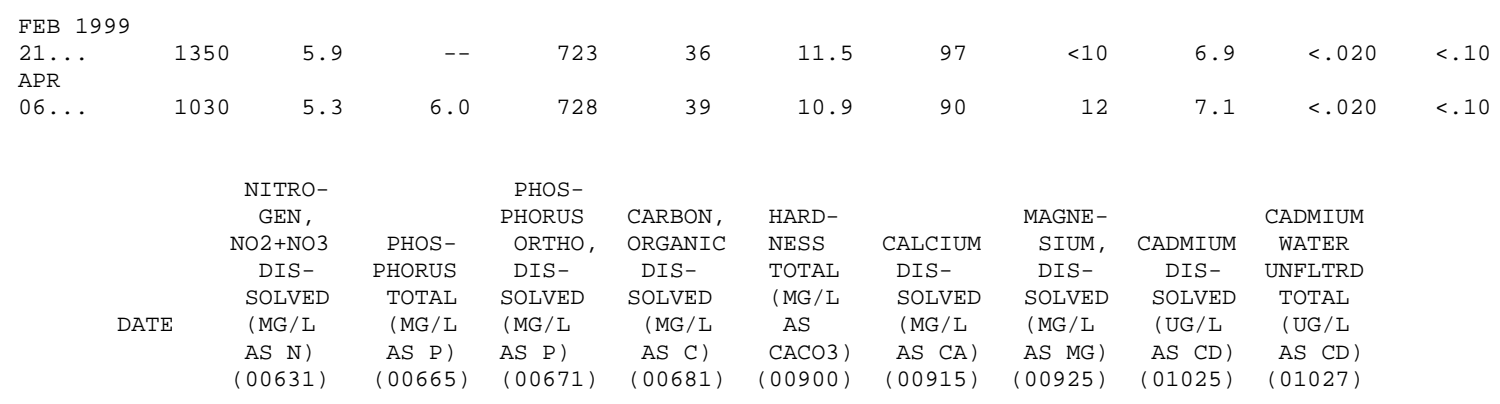

452026121554805 BEAR CREEK DOWNSTREAM OF W FAUBION LOOP BRIDGE, OR (LAT $452031 \mathrm{~N}$ LONG $1215610 \mathrm{~W}$ )

\begin{tabular}{|c|c|c|c|c|c|c|c|c|c|c|}
\hline $21 \ldots$ & .387 & $<.050$ & .002 & .80 & 10 & 2.8 & .67 & $<1.0$ & $<1$ & \\
\hline APR & & & & & & & & & & \\
\hline $06 \ldots$ & .195 & $<.050$ & .002 & .80 & 10 & 2.8 & .71 & $<1.0$ & $<1$ & \\
\hline DATE & $\begin{array}{l}\text { COPPER, } \\
\text { DIS- } \\
\text { SOLVED } \\
\text { (UG/L } \\
\text { AS CU) } \\
(01040)\end{array}$ & $\begin{array}{c}\text { COPPER, } \\
\text { TOTAL } \\
\text { RECOV- } \\
\text { ERABLE } \\
\text { (UG/L } \\
\text { AS CU) } \\
(01042)\end{array}$ & $\begin{array}{l}\text { LEAD, } \\
\text { DIS- } \\
\text { SOLVED } \\
\text { (UG/L } \\
\text { AS PB) } \\
(01049)\end{array}$ & $\begin{array}{l}\text { LEAD, } \\
\text { TOTAL } \\
\text { RECOV- } \\
\text { ERABLE } \\
(\text { UG/L } \\
\text { AS PB) } \\
(01051)\end{array}$ & $\begin{array}{c}\text { ZINC, } \\
\text { DIS- } \\
\text { SOLVED } \\
\text { (UG/L } \\
\text { AS ZN) } \\
(01090)\end{array}$ & $\begin{array}{l}\text { ZINC, } \\
\text { TOTAL } \\
\text { RECOV- } \\
\text { ERABLE } \\
\text { (UG/L } \\
\text { AS ZN) } \\
(01092)\end{array}$ & $\begin{array}{c}\text { SED. } \\
\text { SUSP. } \\
\text { SIEVE } \\
\text { DIAM. } \\
\text { \% FINER } \\
\text { THAN } \\
.062 \text { MM } \\
(70331)\end{array}$ & $\begin{array}{l}\text { BOD } \\
\text { OXYGEN } \\
\text { DEMAND, } \\
\text { BIOCHEM } \\
\text { CARBON. } \\
5 \text { DAY } \\
(\text { MG/L) } \\
(80082)\end{array}$ & $\begin{array}{l}\text { OXYGEN } \\
\text { DEMAND, } \\
\text { BIOCHEM } \\
\text { CARBON. } \\
20 \\
(\text { MG/L) } \\
(80087)\end{array}$ & $\begin{array}{l}\text { SEDI- } \\
\text { MENT, } \\
\text { SUS- } \\
\text { PENDED } \\
(\text { MG/L) } \\
(80154)\end{array}$ \\
\hline
\end{tabular}

452026121554805 BEAR CREEK DOWNSTREAM OF W FAUBION LOOP BRIDGE, OR (LAT $452031 \mathrm{~N}$ LONG 12156 10W)

\begin{tabular}{|c|c|c|c|c|c|c|c|c|c|c|}
\hline $21 \ldots$ & $<1.0$ & $<1$ & $<1.0$ & $<1$ & $<20$ & $<10$ & -- & .3 & .7 & 0 \\
\hline \multicolumn{11}{|l|}{ APR } \\
\hline $06 \ldots$ & $<1.0$ & $<1$ & $<1.0$ & $<1$ & $<20$ & $<10$ & 60 & .2 & .7 & 1 \\
\hline
\end{tabular}

